\title{
THE EFFECT OF HIGH TEMPERATURE ON THE FREE AMINO ACIDS OF COMMON PEA (PISUM SATIVUM L.)
}

By

ESMAIL HOSSEINI SHOKRAII

\begin{abstract}
A DISSERTATION PRESENTED TO THE GRADUATE COUNCIL OF THE UNIVERSITY OF FLORIDA IN PARTIAL FULFILLMENT OF THE REQUIREMENTS FOR THE DEGREE OF DOCTOR OF PHILOSOPHY
\end{abstract}

UNIVERSITY OF FLORIDA

April, 1965 


$$
\begin{aligned}
& 463.36 \\
& 5559
\end{aligned}
$$

AGis-

CULTURAL

LIBRARY

UNIVERSITY OF FLORIDA

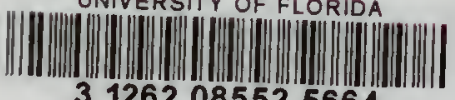

31262085525664 


\section{ACKNOWLEDGMENTS}

The author wishes to express his best gratitude and thanks to Dr. David S. Anthony, Chairman of the Committee, for his kindness and continuous supervision during the pursuit of this degree, especially during the course of research and preparation of this dissertation.

The assistance of the members of the committee, Dr. G. Ray Noggle, Dr. R. H. Biggs, Dr. A. D. Conger and Dr. G. J. Fritz is also gratefully acknowledged. Appreciation is also extended to the Fulbright Commission, the American Friends of the Middle East, University of Florida and the Department of Botany for their very generous fellowships and assistantships which made it possible for the author to extend his graduate studies at the University of Florida. 
IIST OF TABLES. . . . . . . . . . . . . . V v

IIST OF FIGURES . . . . . . . . . . . . . . vi v

INTRODUCTION. . . . . . . . . . . . . . . . I

IITERATURE REVIEW . . . . . . . . . . . . . 9

A. Effects of high temperature on

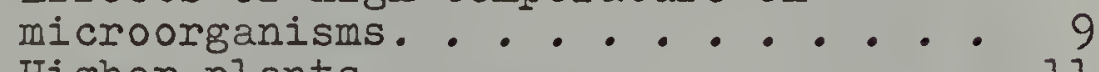

B. Higher plants.......... . 11

MATERIALS AND METHODS . . . . . . . . . . 22

A. Plant material and growing conditions 22

B. Sampling. . . . . . . . . 23

C. Preparation of extracts for amino

acid analysis. . . . . . . 24

D. Purification of extracts by ion-

巴. Qualitative identification of amino

acids in the extracts. . . . . . 25

F. Quantitative determination of soluble amino acios in pea extracts. . . 26

G. Protein determination . . : : 37

H. Chemical treatment techniques... 40

SAMPLING AND PHYSIOLOGICAL AGE. . . . . . . . 43

RESULTS AND DISCUSSION . . . . . . . . . . . 47

I. Growth Characteristics of Plants Under

Optimum and High Temperature Conditions. . 47

II. Amino Acid Analyses of Peas Under Optimum and High Temperature Conditions. . . . 65

II. Protein Estimation. . . . . . . . . 88 
IV. The Effects of Added Metabolites at High

$$
\text { Temperature............. } 105
$$

SUMIIARY AND CONCLUSIONS. . . . . . . . . . 109

IITERATURE CITED . . . . . . . . . . . . . 115

BIOGRAPHICAL SKETCH. . . . . . . . . . . . 122 


\section{IIST OF TABLES}

Table

1. Growing Conditions in Growth Chamber . . . . 23

2. Preparation of Buffers . . . . . . . . 30

3. Percentage Recovery of Amino Acids from the Long and Short Column. . . . . . . . . 33

4. Composition of Metabolite Solutions Sprayed on Leaves . . . . . . . . . . . . 4 42

5. Amino Acid Content of Leaves - First Period of Sampling . . . . . . . . . . . 70

6. Amino Acid Content of Leaves - Second Period of Sampling. . . . . . . . . . . . 73

7. Amino Acid Content of Root - Second Period of Sampling . . . . . . . . . . . 76

8. Amino Acid Content of Leaves - Third Period of Sampling . . . . . . . . . . . . . 81

9. Amino Acid Content of Leaves - Fourth Period of Sampling. . . . . . . . . . . . . .

10. Amino Acid Content of Ieaves - Fifth Period of Sampling . . . . . . . . . . . . . .

11. Protein Content of Leaves. . . . . . . . 102 


\section{IIST OF FIGURES}

Figure

Page

1. Daily height increase of pea plants under two temperature regimes......... . 49

2. Growth (height increase) of the pea plants under high and optimum temperature conditions as compared with the groups of plants which were depistillated (in order to stop fruit formation) at the optimum temperature condition 51

3. Daily height increase at optimum condition (pistil removed).............. 54

4. Total fresh weight increase and the weekly increase of fresh weight at high and optimum temperature conditions. . . . . . . . 58

5. Total dry weight increase and the weekly increase of dry weight at high and optimum temperature conditions. . . . . . . . . . .

6. Increase in percent dry weight at different stages of growth at optimum and high temperature conditions. . . . . . . . 64

7. Shoot-root weight ratio versus time . . . . 64

8. Chromatograms comparing amino acid constituents of leaves of pea plants under optimum and high temperature conditions........... 75

9. Chromatograms of amino acid constituents of roots at optimum and high temperature conditions.

10. Chromatograms of amino acid constituents of leaves at optimum and high temperature. . . .

11. Chromatograms of amino acid constituents of leaves at optimum and high temperature. . . . 
12. Chromatograms of amino acid constituents of leaves at optimum and high temperature.

(Fifth period of sampling) . . . . . . . .

13. Histograms comparing the changes in the amount of aspartic acid, asparagine, glutamine and glutamic acid in the leaves of plants grown under optimum and high temperature during five successive weeks of growth . . . . . . .

14. Histograms comparing the changes in the amount of alanine, serine, glycine and threonine in the leaves of plants grown under optimum and high temperature during five successive weeks of growth. . . . . . . . . . . . .

15. Histograms comparing the changes in the amount of homoserine, valine, leucine and isoleucine in the leaves of plants grown under optimum and high temperature during five successive weeks of growth. . . . . . . . . . .

16. Histograms comparing the changes in the amount of -aminobutyric acid, lysine, histidine and phenylalanine plus tyrosine in the leaves of plants grown under optimum and high temperature during five successive weeks of growth ................. 100

17. Total soluble protein content of leaves of the plants grown under optimum and high temperature during five successive weeks of growth. . 104

18. Total amino acid content of leaves of plants grown under optimum and high temperature conditions during five successive weeks of growth 


\section{INTRODUCTION}

In spite of the large amount of descriptive and morphological information available concerning the effects of high temperature on plant growth and development, especially with the invention of modern climatic control facilities such as growth chambers and the phytotron (78), little is known of the biochemical effects of high temperature on plants. Further research in this area should be quite interesting and hopefuliy fruitful from agricultural and physiological points of view. There are many economic plants that are restricted to certain areas mainly because of their requirement for a certain temperature range. Further studies in this field seem to be quite necessary to develop the fundamental information needed to establish rational approaches 'to such problems as treatment of climatic lesions and the adaptation of different plants of temperature zones to tropical and sub-tropical areas or vice versa. Such research would provide basic information about one of the most important variables of growth in plants -- a variable which has not been thoroughly investigated $(28,29)$.

There is little information concerning the major 
factors that limit plant growth and development at high temperatures, but in general one can cite the hypothesis that plant growth or stage of development may be altered. through limitation of the velocity of a single reaction. Thus, limitation of a single or a few necessary critical substances may cause the changes in growth and development. According to the present concepts of molecular biology, the destruction of proteins, DNA or RNA might cause limitation of growth at high temperature. (High temperature might more correctly be called supra-optimal temperature, but is seldom so described in the literature or in the present paper.) Thermal studies on soluble RNA in vitro revealed the maximum temperature limit for acceptance of amino acids is around $75^{\circ} \mathrm{C}$. The "melting apart" of the two strands of DNA at an elevated temperature is also widely reported, and it is believed that the temperature at which strand separation of DNA could occur is in the range of $70^{\circ} \mathrm{C}$. to $90^{\circ}$ C. (i8).

The greatest range of adaptation to temperature is found in microorganisms, where some species are found that are able to grow at $-4^{\circ} \mathrm{C}$, and others to $+70^{\circ} \mathrm{C} .(30)$. Several fungi may also grow below $0^{\circ} \mathrm{C}$, , but their upper limit of growth is $40^{\circ} \mathrm{C}$. to $50^{\circ} \mathrm{C}$. Of course, duration of temperature is important since, for a short period of time, some spores can tolerate temperatures as high as $130^{\circ} \mathrm{C}$. 
(The temperature limits of growth and development in poikilothermic organism are tabulated in the "Handbook of Biological Data" by Spector (68).)

The highest temperature at which organisms grow on the earth's surface are found in hot spring areas in the Yellowstone region of the United States, in Japan, New Zealand and Iceland (10). There are numerous reports of algae and bacteria found in these places where the highest temperature is $73^{\circ} \mathrm{C}$. Studies by Koffler (33) on life in hot springs indicate that the thermophilic organisms have evolved some kind of protein that is much more thermostable than that of mesophilic species.

Flowering plants appear to have temperature limits. similar to those of fungi, as they can grow at several degrees below zero and at temperatures above $50^{\circ} \mathrm{C}$. The temperature limits of desertic plants have been discussed briefly by Kurtz (35) and the maximum is found in desert areas of the United States. Among the members of the cactus family there are species like Opuntia that grow at temperatures as high as $58^{\circ} \mathrm{C}$ : In Australian deserts, some species of Atriplex, e.g. A. vesicarium, exhibit a maximum rate of photosynthesis at $40^{\circ} \mathrm{C}$. to $50^{\circ} \mathrm{C}$. Most of these desertic plants are obligate thermophiles. The lethal high temperature according to Lorenz (48) varies with: 1) species of plant; 2) duration and method of application of temperature, 
since gradual increase of temperature has a much less harmful effect; 3) age of tissue and organ; 4) time of exposure to high temperature (day or night); 5) part of plant (root or shoot), tops of plants are more resistant than roots. This last mentioned phenomenon may be due to the presence of more protective tissue around the stem and leaves rather than to difference in heat tolerance of protoplasm.

The damage caused by higher than optimum temperature on flowering plants and lower plants. seems to be mediated in large part by an effect on some chemical reactions. within the plants. However, only in a very few cases has the biochemistry of the plants been studied in relation to high temperature as was mentioned before $(36,42)$.

Although there is little information on reactions affected, there are observations of biochemical differences which have been attributed to high temperature such as: change of amount of aromatic compounds in flowers and fruits (especially in the tea plant), decrease of soluble sugar, formation of pigments, and changes in pigment concentration of leaves, flowers and fruits. The red and pink colors often become more pronounced at lower temperatures since anthocyanin pigment formation actually is responsive to sugar content which in turn is affected by temperature. Growth, as determined by fresh weight and dry weight, reduces at high temperatures. The cause of this reduction 
is not really understood, al though several explanations are offered. Many investigators believe that decrease in growth of plants at temperatures above optimum is partly due to limitation of translocation. Temperature affects translocation (77). Maximum translocation occurs at about $10^{\circ} \mathrm{C}$. in many plants. Thus, indirectly, root weight might change with high temperatures as root weight is quite responsive to rate of translocation. High temperature causes an increase in respiration greater than an increase in photosynthesis, and this would cause a decrease of growth mostly due to reduction in sugar and other reserve materials $(4,20,26,47)$. Nightingale (59) reports that orchard trees are able to accumulate more carbohydrate at moderate ratber than at bigh temperatures. In sugar beets there is an inverse correlation between the amount of sugar and the temperature of the environment. Finally, among the other effects of high temperature that could affect. growth are mentioned susceptibility of plants to disease and also the increased phytotoxicity of toxic compounds, e.g. $2,4 \mathrm{D}$ is more toxic at high temperature than at low temperature.

An interesting and complex interaction between plants and temperature is diurnal and annual thermoperiodicity which are very common among the higher plants. In general, the optimum temperature for night is lower than for day. Spring annuals die when subjected to a bigh night temperature 
of about $25^{\circ} \mathrm{C}$. , although they will grow well at a day temperature of $25^{\circ} \mathrm{C}$.

It has been observed $(34,78,79)$ that in certain plants resistance to cold can be increased by growing them under a condition of alternating light and dark in which the daily rhythm is not a 24 hour cycle, but somewhat longer. On the other hand, the same plant can be made resistant to high temperature damage by growing it under a daily cycle of less than 24 hours.

All these facts suggest that most plants do have a kind of timing mechanism or a diurnal rhythm which seems to coincide with a 24 hour period (8) at optimum temperature. At low temperature the cycle of diurnal rhythm is slower, and there is a failure of synchrony between the plant and outside environment. This in turn can cause metabolic imbalance and possible visible disturbances.

In general, the factors that have been suggested as responsible for the effects of higher than optimum temperature on plants could be summarized as follows (42):

Change (decrease) in availability of gases. In some microorganisms it has been shown that high temperature has a direct effect only on the availability and amount of gases dissolved in the culture medium.

Acceleration of breakdown of enzymes, vitamins and other metabolites.-Again, extensive experiments with 
microorganisms in controlled culture media have shown that the requirement of the organism for a growth factor or enzyme will rapidly increase with elevation of temperature.

Changes in the balance of interconnected reactions.Temperature extremes thus might cause accumulation of some toxic products, or reduction of necessary factors. In either case, the regulation of metabolism would change. Consequently, growth would be affected.

Enzyme inactivation:-Studies with microorganisms support the idea that simple inactivation of a single thermolabile enzyme could result in a lesion due to higher. than optimum temperature, e.g., the high heat sensitivity of nicotinamide adenine dinucleotide $\left(\mathrm{NADH}_{2}\right)$ oxidase has been demonstrated in microorganisms. A similar effect of high temperature on enzymes of higher plants could exist. Inhibition of enzyme formation. The effect of high temperature inhibition of the formation of an enzyme can be due to either inactivation and destruction of RNA, or the inhibition of activity of the operator gene for enzyme formation.

Enzyme activation.-Several experiments show that heat activation of an enzyme might occur, since heat can destroy a thermolabile inhibitor of an enzyme and thus cause indirectly an activation of an enzyme reaction. 
In biochemical studies of higher than optimum temperature it is important to select a plant that has the following qualifications:

It should be sensitive to high temperature.

It must have a rather short life span to make large numbers of replicates possible in a reasonable time. It should be rather small in size to be carried and handled easily in controlled conditions. It. should be able to grow well under controlled conditions and also in artificial media.

There are other important points to consider in addition to choice of plant material. The method of application of high temperature must be considered. Is high temperature going to be given only at the beginning of germination or during maturity?. Another question to consider is the duration and intensity of the high temperature stress. 


\section{IITERATURE REVIEW}

A. Effects of high temperature on microorganisms

The largest body of work on the biochemical effects of temperature considered to be higher than optimum has been done using microorganisms.

It has been shown in a number of microorganisms that the reduction in growth rate which occurs at higher than optimum temperatures could be prevented or maximum growth could be restored by supplying a specific chemical (metabolite) in the growth medium. If the temperature was much higher than optimum, adition of that specific metabolite had to be greatly increased or a combination of two or three different metabolites was required to restore the growth of the microorganism to or toward normal (42).

If the temperature was dropped back from supraoptimum to optimum, maximum growth was restored without the further addition of any of the metabolites.

The so-called temperature sensitive mutants of Neurospora crassa and Escherichia coli have been extensively studied $(2,51,52,57)$. It has been shown that Neurospora crassa can grow quite well at temperatures up to $35^{\circ} \mathrm{C}$. to $40^{\circ} \mathrm{C}$. , however, there is a mutant of Neurospora which grows 
well at or below $25^{\circ} \mathrm{C}$. Its growth rate decreases markedly with further increase of temperature until at $28^{\circ} \mathrm{C}$. growth stops completely. Growth can be restored at $28^{\circ} \mathrm{C}$. in this microorzanism by addition of $2.5 \times 10^{-4} \mathrm{gm}$ of riboflavin to each liter of culture solution. There seems to be a perfect riboflavin-temperature-growth response interaction (57).

Other mutants have been found that can be protected against the development of high temperature lesions by simultaneous supplementation with adenine, pyrimidine and methionine in their media (55). A temperature sensitive uracil-requiring mutant has also been isolated (25) where there is a complete block for uracil synthesis at high temperature. Addition of uracil to the growth medium of this organism causes normal growth even at temperatures higher than optimum. Temperature-dependent tyrosine requirement in Neurospora also has been reported (24) and was interpreted as a result of lower thermostability of the mutant enzyme. Addition of typrosine prevented the defect. In E. coli, panthothenate-requiring temperaturesensitive mutants have been isolated. In this microorganism, the enzyme responsible for the condensation of $\beta$-alanine and pantoic acid to form pantotbenic acid is apparently more heat labile than other enzymes. Thus, the addition of panthothenic acid to cultures of this temperature-sensitive mutant allows them to grow at elevated temperatures in a manner 
identical with normal strains. Among the organic compounds which have been found to reduce high temperature damage in one or more of a large group of microorganisms and fungi by several investigators $(3,9,14,61,65)$ one may mention: methionine, glutamic acid, thiamin, biotin, a number of other amino acids, and other members of the vitamin $B$ complex.

In some instances there is no inhibition of growth because of high temperature, but, on the other hand, Hertman (19) has seen the induction of impairment of some biochemical processes. For instance, in pasteurella pestis at $37^{\circ} \mathrm{C}$. (optimum temperature is $27^{\circ} \mathrm{C}$.) the formation of pesticin stops. At high temperature, addition of amino acids such as leucine and/or isoleucine relieves the high temperature effect, and pesticin can be produced the same as under optimum temperature.

\section{B. Higher plants}

Some of the earliest work on the biochemical effects of abnormal temperature was by James Bonner (7) who proposed the term "climatic lesion" for the first time. His concept was that at higher or lower than optimum temperature one or several biochemical events cannot take place simply because the enzymes responsible for those biochemical syntheses are more thermolabile than other enzymes. Therefore, after a short time there would be a shortage of those particular metabolites. Bonner proposed that the shortage of such 
metabolites is the cause of the "climatic lesion" and that the lesion might be cured by external supplementation of the particular compound or compounds which were absent. In other words, under unfavorable temperature conditions, green plants become heterotrophic for one or more specific metabolites. Bonner tested his theories by experiments with Cosmos (6). However, his published data are all concerned with the effects of low temperature. He found the addition of thiamin in the nutrition medium of the Cosmos caused an increase of growth as measured by fresh weight at temperatures lower than optimum. His results were most significant where dry Weight was as low as 5 per cent of that under optimum conditions. Under these circumstances, thiamin caused a 40 per cent increase in dry weight. At a temperature where ary weight was half of maximum, the increase due to thiamin addition was 20 per cent. Addition of thiamin at the optimum temperature had no stimulatory effect on growth. The conclusion was made that at low temperature, inhibition of growth of the Cosmos plant can be overcome by an external source of thiamin. This is the first recorded successful chemical prevention of a climatic lesion. Later work on prevention of low temperature damage on eggplant (solanum melongens) (32) has shown a low temperature (140 C. night; $20^{\circ} \mathrm{C}$. day) inhibition of growth can be overcome with a mixture of ribosides sprayed on the leaves. While at optimum 
temperature $\left(23^{\circ} \mathrm{C}\right.$. night; $30^{\circ} \mathrm{C}$. day) ribosiales have little or no effect. With tomato plants it has been shown that soaking of seeds in a solution of nicotinic acid caused significant increase in tolerance of seedings to low temperature inlibition of growth (32).

The alleviation of a high temperature lesion appears to have been accomplished for the first time by Galston and Hand (15). They showed that, in etoilated pea epicotyl sections and also in excised etoilated leaves, the addition of adenine to the growth medium decreased the high temperature inhibition of growth. Adenine stimulation of growth at optimum temperature was only half as much at high temperature $\left(35^{\circ} \mathrm{C}_{0}\right)$. They concluded that inhibition of growth at high temperature in the pea tissue was partiy due to adenine destruction or inhibition of its synthesis. Further work by Galston (17) on growth of intact pea plants (var. Alaska) in the Earhart Phytotron Laboratory did not show a complete reversal of high temperature-induced decrease of growth by adenine supplementation where plants were kept at high night temperature and optimum day temperature. Possibly the failure of successful cure of high temperature lesions with adenine in this case was due to the use of high night temperature as the experimental condition, whereas later it was shown that the pea is more sensitive to high day temperatures (16). Iater work of Iockhart (46) with the same variety of 
pea indicated that adenine had no significant effect on stem elongation and growth or on onset of maturity of the whole pea plant kept at $30^{\circ} \mathrm{C}$. However, it should be noted that the plants in this study were kept at a constant high temperature (day and night).

Despite the inconsistencies with respect to adenine supplementation cited above, it is possible that adenine may have some importance; because the adenine level in high temperature-resistant pea plants increased with high temperature conditions while in a temperature-sensitive strain, adenine decreased (22).

Additional evidence that adenine deficiency may be a cause of high temperature injury in plants was obtained by McCune (54) with the common duckweed (Lemna minor). He showed that this plant could be protected against high temperature damage by the addition of adenine in the form of adenosine to its culture medium. Guanosine also was found to be effective.

Additional work, showing climatic lesions and their chemical treatment in peas, was reported by Ketellapper and Bonner (31). They found that mixtures of essential metabolites such as a vitamin B mixture, or a riboside mixture, partially or completely prevented the reduction of growth at high temperatures. Sucrose and vitamin $C$ also were found to be effective. Ketellapper (32) found that inhibition of 
growth at a temperature a few degrees higher than optimum coula be completely stopped by a spray of sucrose on leaves while for conditions several degrees higher than optimum there was no significant effect for sucrose. This indicated that sucrose and other metabolite effects are temperature specific. It seems probable that at least part of the high temperature response is mediated through the chemical machinery of the plant, although the experimental evidence is often confusing.

The study and interpretation of climatic lesions due to high temperature in plants is complicated by several factors. For example, within a given genus and species there may be strains or varieties showing both quantitative and qualitative differences in response to temperatures. Langridge $(39,40)$, working with a wide range of strains of Arabidopsis thaliana, showed that the inhibition of growth at elevated temperatures varied markedly from strain to strain. Further, he showed that the high temperature inbibition of growth was prevented in certain Arabidopsis strains by the addition of biotin, in another strain by cytidine, in another by choline, while in still other strains he was unable to prevent the high temperature effect by chemical means. Ketellapper (32) also warned that the effective substances for preventing high temperature effects may vary from species to species, and even from variety to variety within a species. 
Interpretation of negative results in experiments involving attempted cure or reversal of climatic lesions by chemical means is difficult since one may not be sure Whether the added.compound actually reached the affected tissue (32).

Another surprising complication even within a given genus, species and variety in the study of high temperature effects is the variation due to seed source. In research with peas (var. Unica), Highkin $(21,22)$ fownd that the conditions under which the seeds had been grown altered the effects of subsequent temperature treatment. He found that constant day and night temperatures maintained over several generations successively reduced the vigor of progeny in a cumulative sense. Further, seeds from plants that had been maintained for a few generations at constant temperature did not produce plants of normal vigor when planted at optimal fluctuating temperatures until the second or third generation under the optimum conditions. Subsequently, Ketellapper (32), with the same pea variety, showed that the effect of high temperature on growth is counteracted either by sucrose or by a vitamin $B$ mixture and a riboside mixture, depending on seed source (i.e. temperature conditions under which seed had been grown). These results suggested that the phenotype is a combination of its genetic heritage, its present environment, and the environmental conditions under which its parent grew $(23,41)$. 
Langridge (42) believes a number of these growth stimulations by chemicals reported above for higher plants is of poor reproducibility and of doubtful statistical significance, thus is in contrast to the high temperature lesions that have been observed among microorganisms. In the work with Arabidopsis thaliana already described, Langridge and Griffing (40) did obtain clearcut, significant responses to chemical additions at high temperatures in aseptic culture.

Another interesting aspect of high temperature effects on plants from the biochemical point of view is the effect of high temperature on the response to auxin and gibberellin. Galston (16) and Lockhart (46) studied responses of plants to hormones under high temperature conditions. A silkless mutant variety of corn at $20^{\circ} \mathrm{C}$. day and $14^{\circ} \mathrm{C}$. night temperature showed a 50 per cent elongation response to applied indole acetic acid (IAA), whereas a normal variety gave no response at this temperature regime. However, at a higher temperature, $26^{\circ} \mathrm{C}$. day and $20^{\circ} \mathrm{C}$. night, the silkless variety showed no response to IAA while the normal variety gave a 16 per cent elongation response. Lockhart observed that appliec gibberellin on leaves of Alaska peas grown at high temperature had a very significant effect on delaying the high temperature acceleration of senescence which usually accompanies the onset of maturity. Later, lang $(37,38)$ showed that failure of Hyocyamus in flower formation 
at high temperature is apparently because of gibberellin deficiency rather than anything else since Hyocyamus needs a large amount of gibberelin to elongate the flower stalk. It was shown that gibberelin sprayed on leaves of Hyocyamus and some other plants can replace the need of low night temperature which otherwise was necessary for flower formation. Among the other works that can be considered related to this problem the following papers need to be mentioned. Yarwood $(80,81)$ has studied acquired tolerance of leaves to heat (acquired heat tolerance of microorganism has been known for some time (62)) and also has observed translocation of heat injury from one leaf to another. When leaves of a number of a species of plants were pretreated at a temperature of $50^{\circ} \mathrm{C}$, they subsequently (12, 14 hours later) tolerated a temperature of $55^{\circ} \mathrm{C}$. up to three times as long as did the control leaves which were not previously heated. Also, a temperature of $65^{\circ} \mathrm{C}$. applied unilaterally to plants killed the heated leaves, but at the same time the leaves in the other unheated side or branches became injured without any possible direct heat transfer (81). The above mentioned reports constitute a review of the available literature dealing with the problem of metabolic or biochemical effects of high temperature on plants. From the scattered but divergent results already in the literature, it seems likely that there is not a single general chemical 
explanation for heat injury, but rather there may be many explanations in many plants. Obviously, much more information is needed before any general or specific theory of heat injury, backed by solid evidence, can be elaborated. One omission in studies of high temperature injury in plants became apparent from the literature review. To our knowledge, with the partial exception of one paper in the Russian literature (60), there is no published evidence that anyone has attempted to make quantitative biochemical analyses comparing the composition of plants grown at high temperature with that of the same plant grown at optimum temperatures. That is, there is no direct quantitative measure of the biochemical effects of high temperature on higher plants.

Thus, since technological advancement has recently been made in isolating and identifying most of the biochemical constituents of plants, it seemed reasonablel that an organized investigation of the quantitative effects of heat on the biochemistry of plants might advance our understanding more rapidly than spraying or adding to the plant in "shotgun" fashion a variety of metabolites with the hope that this sprayed mixture contained the substance which was deficient under the high temperature condition. In such experiments, there must be the further hope that the critical substance (or substances) can be taken up and translocated to the site of need. 
However, it was very difficult to decide which groups of compounds should be studied in preference to other groups. The final decision was to study amino acids and proteins. This decision was made for the following reasons.

Davern (II) extended the work of Ketellapper in a study of the effects of amino acids on the growth and development of clover (Trifolium subterraneum), a cold temperature requiring plant. It has been shown that spray of casein hydrohysate on the plant under high temperature has quite a significant effect on the growth, while the effect on plants under optimum conditions is not significant. Davern did not study the effect of each single amino acid but he used three groups of amino acids; protein amino acids, non-protein amino acid and ring-structure amino acids. The first and second groups were found to be much more effective (especially the first group).

Petinov (60), in a research with leaf tissue culture, has shown that high temperature increased the amount of free amino acids. Fe was not looking for a lesion, and his analytical technique was only roughly quantitative (onedimensional paper chromatography).

Earlier work of F. C. Steward (70) has shown the effects of various nutritional conditions as well as light and dark period and high night temperature on the free amino acids of Mentha piperita (mint plant). He has shown that 
amino acids change drastically with changes in the environmental and nutritional variables.

Research on a large group of microorganisms and lower plants have shown that high temperature lesion and inhibition of growth can be prevented or reduced by a number of amino acids $(5,27,66)$.

Levitt $(44,45)$ suggested a possible correlation between frost hardiness and high temperature hardiness. He postulated that both are concerned with protein structure. In view of the available evidence, it seemed reasonable, as a first quantitative approach, to examine the free amino acids and proteins of plants at optimum and supra-optimum temperature, hereafter usually referred to as high temperature conditions. 


\section{MATERIALS AND METHODS}

A. Plant material and growing conditions

Pea seeds (Pisum sativum variety Greater Progress and Wanda)* were hand-graded for uniformity, soaked five hours in tap water at room temperature and then sown in plastic flats ( $15^{\prime \prime} \times 12^{\prime \prime} \times 6.5^{\prime \prime}$ ). The planting medium was a mixture of equal volumes of washed sand and vermiculite. The flats were watered $(2,000 \mathrm{ml})$ and were transferred to growth chambers (Percival Growth Chamber Model E-57). Every day prior to germination of seeds each flat received $500 \mathrm{ml}$ of distilled water. After the seeds germinated, extra seedlings and abnormally small or large seedlings were discarded in order to have a uniform group of seedlings. All flats were thinned to 12 seedlings with approximately equal spacing. Ten days after planting, plants were watered with $500 \mathrm{ml}$ of Hoagland's solution per flat every other day. The plants under high temperature conditions were given additional distilled water occasionally as needed to eliminate water stress. The temperature of nutrient solution was not adjusted beforehand to the temperature of growing conditions (usually it was less, especially at the high temperature condition). The light source was a combination of fluorescent

*Purchased from Joseph Harris Co., Inc., Moreton Farm, Rochester Il, New York. 
TABIE I

Growing Conditions in Growth Chamber

\begin{tabular}{cccc}
\hline $\begin{array}{c}\text { Temperature } \\
\text { condition }\end{array}$ & $\begin{array}{c}\text { Phototemperature } \\
(16 \mathrm{hr} .)\end{array}$ & $\begin{array}{c}\text { Nyctotempcrature } \\
(8 \mathrm{hr} .)\end{array}$ & Light intensity \\
\hline Optimum & $23 \pm 1$ & $17 \pm 1$ & $1200 \pm 200$ s.c. \\
Figh temperature & $30 \pm 1$ & $23 \pm 1$ & $1200 \pm 200$ f.c. \\
\hline
\end{tabular}

(cool white) and incanàescent buibs (Sylvania lamps). For each experimental condition tested 60 plants were usea. Men plants were selected at random after the first week oi growth for measurement of daily height increase.

B. Sampling

Six plants were selected rancomly for each extract. First, they were washed free of rooting medium and weighed immediately. The number of leaves, height of shoot, total and shoot fresh weight, root weight, shoot-root ratio, dry weight and later number of buds, flowers and fruits were measured. Alcoholic extracts were prepared from leaves, roots, and stem. The plant tissues were cut into small $(0.5 \mathrm{~cm})$ pieces and dropped into about $150 \mathrm{mI}$ of 80 per cent ethyl alcohol at room temperature. The alcohol was allowed to remain in contact with the plant tissue curing storage at $0^{\circ}$ C. prion to analysis. (Mhis storage period was from one to three months.) The time or original sampling was the 
same (8:00 P.M.) in the two temperature conditions and usually the time of sampling was 12 hours after watering. Samples were taken once a week.

C. Predaration or exiracts for amino acid analysis

The stored alcoholic extracts and the tissue residue vere homogenized thoroughly in a glass homogenizer and vacuim filtered through thatman fflliter paper. The filtrate was concentrated in a Rinco flasi evaporator under vacuum at room temperature. The concentrated (now aqueous) extract was centrifuged 15 minutes at maximum speed in a clinical centrifuge (approximately $1000 \times$ g). The precipitate was discarded. An equal volume of chloroform was added to the supernatant with vigorous shaking to renove fats ano pigments. The chicroform layer was discarded. The defatted aqueous extract prepared in this way was further concentrated to $1 \mathrm{ml} / \mathrm{I}$ gm wet weight of original plant sample.

D. Purification of exiracts by -or-exchange resin

An ion-exchange column approximately $15 \mathrm{~cm}$ in length, containing 10 gms Dowex 50, was washed several times with distillea water, the Dowex 50 was regenerated by passing $80 \mathrm{ml} 3 \mathrm{~N} \mathrm{FCl}$ through the columin. Since the volume of the $15 \mathrm{~cm}$ resin column was $13 \mathrm{ml}$, the $80 \mathrm{ml} \mathrm{HCl}$ rinse was about siz column volumes (67). The ECl was wasied out by passing 200 or more $m$ l of water through the column until the colume was chloride free (checked with $\mathrm{AgMO}_{3}$ ). The plant extracts 
were passed through the washed colum in ice cold condition (column was placed in ice and wter) at a maximum flow rate of ten arops/minute. At this state, the amino acids were tightly held near the top of the column. The column was rinsed with $100 \mathrm{ml}$ distilled water to wash out the last traces of anionic and neutral materials. The amino acids were then eluted with $\mathrm{NH}_{4} \mathrm{OH}(72)$. The first elution was with $0.15 \mathrm{~N} \mathrm{NH}_{4} \mathrm{OH}(50 \mathrm{ml} / \mathrm{ml}$ of resin bed) and then with $2 \mathrm{~N}$ $\mathrm{NH}_{4} \mathrm{OH}(25 \mathrm{ml} / \mathrm{ml}$ of resin). Elution was also carried out in the cold (column was placed in ice and water). The $\mathrm{NH}_{4} \mathrm{OH}$ elute was collected and the column was washed with distilled water until the eluate was ammonia free (phenolphthalein test). The combined eluates were collected and concentrated unde: vacuum to an appropriate volume (usually l $\mathrm{ml} / \mathrm{lgm}$ fresh tissue). The purified amino acids obtained in this way were adjusted to $\mathrm{pH} 2.25$ and were stored in a freezer $\left(-15^{\circ} \mathrm{C.}\right)$. The resin column was regenerated for the next run by washing with $3 \mathrm{~N} \mathrm{FCl} \mathrm{(} 6 \mathrm{ml} / \mathrm{HCl} / \mathrm{l} \mathrm{ml}$ resin bed).

E. Qualitative identification $0=$ amino acids in the extracts

Two-dimensional paper chromatography was used to separate and identify the amino acids. A sample of 100 ul of plant extract prepared as described in section D was placed as a single small spot in the corner $(2.5 \mathrm{~cm}$ from each of the two edges) of a $30 \times 40 \mathrm{~cm}$ piece of Whatman \#3 paper. The spotted paper was developed in a chromatographic 
chamber, which was maintained at approximately $25^{\circ} \mathrm{C}$., in an air-conditioned rcom. The solvent used were: butanol, acetic acid and $\mathrm{H}_{2} \mathrm{O}$ for the first phase and phenol-water, for the second phase (71,75). Preparation of solvents: 1) $125 \mathrm{ml}$ butanol plus $125 \mathrm{ml}$ water plus $30 \mathrm{ml}$ acetic acid (lower phase discarded) upper phase was used for paper chromatography, $150 \mathrm{ml}$ of solvent were used in one trough for two papers; 2) $160 \mathrm{ml}$ of pure phenol and $40 \mathrm{ml}$ of distilled water plus $0.5 \mathrm{ml}$ of ammonia. Equilibration time of papers and solvents in chromatographic chamber was alvays two hours. A I per cent solution of ninhydrin in acetone was used to stain amino acid spots. Paper chromatograms of known amino acids were first prepared, and then they were used to compare with those of the plant extract chromatogram to identify the kind and number of the soluble amino acids present in the extract. The colored spots were eluted with $10 \mathrm{mI} 50$ per cent ETOH and the optical density was determined spectrophotometrically $(72,73,74)$.

E. Quantitative determination of soluble amino acids in pea extracts

After repeated tests, we rejected paper chromatography as a quantitative method for amino acids because the method did not yield consistent results. The equipment and technique available to us allowed only a qualitative or rough quantitative measure of the amino acias. 
For quantitative separation and measurement of the amino acids in our extracts, we used an adaptation of the ion-exchange separation method of Moore, Spackman and Stein (58).

1. Preparation of ion-exchange columns. The acidic and neutral amino acids were separated in a column of cation exchange resin Aminex-MS IR-120 Fraction D, particle size $56 \pm 9$ u.* The resin bed was $150 \mathrm{~cm}$ long. The basic amino acids were separated on another column of Aminex-MS, Fraction C, particle size $40 \pm 7 \mathrm{u} . *$ The resin bed was $15 \mathrm{~cm}$ long. The temperature in both columns was kept constant by the presence of a water jacket around the columns through which water of the desired temperature was circulated. Elution was accomplished by passing solutions of sodium citrate buffer of appropriate pH values through the columns. For separation of the acid and neutral amino acids, a thick walled chromatographic column (obtained from Scientific Glass Apparatus Company) $0.9 \mathrm{~cm}$ inside diameter and $165 \mathrm{~cm}$ in length was used. In the bottom of the column was a sintered plate to retain the resin. The resin was washed with four times its volume of distlled water, then washed twice with $0.2 \mathrm{~N}$ pH 3.25 citrate buffer. The resin was kept in slurry form in the buffer until used. Packing of the long California.

Purchased from BIO-Rad Laboratories, Richmond, 
column was done in five sections. Before the first section of resin was poured the outlet of the column was closed. Then a slumy containing one-fifth of the total resin in buffer was adced to the column. Mne amount used in this, and in foun subsequent acalitions, was $19.6 \mathrm{gm}$ of resin in $60 \mathrm{ml}$ of buffer. After the slurry had been added, the column outlet was openea, and after $1 \mathrm{~cm}$ of resin bea was settlea. uncer gravity flow, then ain pressure $(5.8 \mathrm{psi}=30 \mathrm{~cm}$ mercury) was applied at the top of the column. After the resin settled to constant height, the supernatant extra buffer was withdrawn and the next section was poured on top of the firm surface of the first section. The procedure was tien repeated for each aćditional section lntil all five sections had jeen ad̀de⿳亠 anc packed. The final height of resin must be several centimeters more tian $150 \mathrm{~cm}$ to allow for further packing of resin during operation. (It was $161 \mathrm{~cm}$ in the beginning.) An extension tube was attached to the top of the chromatographic column by means of rubber thioing, and this in turn was connected to a separatory funnel containing buffer. A pinch clamp was installed below the funnel. Before the colurn was used it was treated with 100 ml of $0.2 \mathrm{~N}$ NaOE and then was equilibrated with buffer of pF 3.25. The rate of flow was $18 \mathrm{ml} / \mathrm{hr}$. This flow rate was maintained by applying an ain pressure of 3.2 psi to the top of the buffer reservoin (separatory funnel), during colum 
operation (temperature during operation of long colum was $49 \pm 1^{\circ}$ C.).

For separation of the basic amino acids, a short column ( $15 \mathrm{~cm}$ ) was prepared with $12 \mathrm{gm}$ of Aminex-Ms Resin (Fraction $C$, size of particle $40 \pm 7 \mathrm{u}$ ). The resin was washed carefully several times with distilled water and then three times with citrate buffer of $\mathrm{pH} 4.25$. The column was packed under five pounds pressure in two sections, in a manner similar to the packing of the long column. During operation, the column was usually under two pounds of air pressure at $30^{\circ} \mathrm{C}$, and it had a flow rate of $22 \mathrm{ml} / \mathrm{hr}$. This column was used only for the basic amino acids, and it took only nine hours for one extract to be analyzed. Citrate buffers of different pH were prepared as shown in Table 2. Thiodigljcol (MG) was added to the buffers before use. Brij 35 detergent was used only once every four to five weeks since it caused problems in work with the drop counter. (Brij 35 reduces surface tension and thus the volume of arops change.) It was necessary to wash the column after Brij 35 addition for two to three days to eliminate Brij 35 effect. In all the citrate buffers, phenol protected the buffer against microbiological activity. A final adjustment of $\mathrm{pH}$ of the buffers was necessary, usually $\mathrm{I} \mathrm{ml}$. of 50 per cent $\mathrm{NaOH}$ or $2 \mathrm{ml}$ of concentrated HCl caused a change of about 0.01 unit in pH value of the buffers ( 1 Iiter). 
TABLE 2

Preparation of Buffers

\begin{tabular}{|c|c|c|c|c|c|c|c|c|}
\hline $\mathrm{pH}$ & $\begin{array}{c}\mathrm{Na} \\
\text { Conc. } \\
\text { (normal) }\end{array}$ & $\begin{array}{c}\text { Citric } \\
\text { acid } \\
\text { gm }\end{array}$ & $\begin{array}{r}\mathrm{NaOH} \\
97 \% \\
\mathrm{gn} \\
\end{array}$ & $\begin{array}{c}\mathrm{HCl} \\
(\mathrm{conc} .) \\
\mathrm{m} 1\end{array}$ & $\begin{array}{l}\text { Water to a } \\
\text { final Vol. } \\
\text { of (iiter) }\end{array}$ & $\begin{array}{c}\text { Phenol } \\
\mathrm{gm}\end{array}$ & $\begin{array}{l}\text { TG* } \\
\mathrm{m} 1\end{array}$ & $\begin{array}{l}\text { Brij } j^{+} \\
35 \mathrm{ml}\end{array}$ \\
\hline 2.25 & 0.20 & 105 & 42 & 80 & 5 & 5 & & \\
\hline 3.25 & 0.20 & 840 & 330 & 426 & 40 & 40 & 10 & 5 \\
\hline 4.25 & 0.20 & 840 & 330 & 118 & 40 & 40 & 10 & 5 \\
\hline 5.28 & 0.35 & 491 & 288 & 136 & 20 & 20 & & 5 \\
\hline 4.26 & 0.38 & 532 & 312 & 307 & 20 & 20 & & 5 \\
\hline
\end{tabular}

*TG (Thiodiglycol).

Brij 35 detergent solution--prepared by dissolving $50 \mathrm{gm}$ of Brij 35 in $150 \mathrm{ml}$ hot $\mathrm{H}_{2} \mathrm{O}$. 
To prevent bubble formation when the temperature was raised to $50^{\circ} \mathrm{C}$. in the column, it was necessary to boil the buffer. (Volume of buffer should be checked after boiling, in order to keep Na concentration constant.) Hot buffer was transferred to the separatory funnel (buffer reservoir) via a long-necked funnel to introduce the boiled buffer below the level of a paraffin oil lajer constantly maintained in the buffer reservoir. (There must always be a lajer of oil over the buffer to prevent air mixture with buffer.) Additional buffer for immediate use was kept under a layer of paraffin oil. The buffer reservoir was connected to the top of the column via two male and female ball joints (a small amount of vacuum grease was always used to make tight connection).

2. Operation of the long column (for neutral and basic amino acids). The load of the column should not be very much nore than the amount that was used for paper chromatography, usually about 1.0 umole of each amino acid was satisfactory. A sample of the purified plant extract was applied on top of the resin bed with a bent tip pipette (that is, it was carefully run down the glass wall of the column in order not to disturb the surface of the resin bed). The temperature of the column was brought to $50^{\circ} \mathrm{C}$. before the addition of sample, then 3.2 pounds pressure was applied until the top surface of the extract layer was brought to 
the resin surface in the column. Then, $1 \mathrm{ml}$ of buffer at pH 2.25 was added and after this, buffer also was brought level with the top of the resin bed. Then the column was connected to the separatory funnel containing pH 3.25 buffer. Air pressure of 3.25 psi was applieà. Effluent was collected in I ml fractions with a fraction collector (Research Specialties Co., Mod. 1205). After 260 tubes were collected, buffer at pH $4.25(0.2 \mathrm{~N} \mathrm{Na})$ was substituted for the buffer at pH 3.25 to elute the neutral amino acids. Usually, in the long column the time for a single extract analysis was about 24 hours (up to the isoleucine and leucine peak).

To determine the location of different amino acids in the effluent, a series of known amino acids was tried. After the location of each amino acid was known, several tests on synthetic mixtures were made to make sure of reproductibility and also the percentages of recovery of amino acicis from the column. The order of appearance and degree of separation of the peaks was completely reproducible. Recovery percentages for each amino acid were determined as shown in Table 3. The column must be renovated after each run, since otherwise all basic amino acids will be retained in the column. Renovation is accomplished simply by passing $100 \mathrm{ml}$ of $0.2 \mathrm{~N} \mathrm{NaOH}$ through the column. Subsequently, the column must be washed thoroughly with the appropriate buffer to become readjusted before being reused. There is no need 
TABLE 3

Percentage Recovery of Amino Acids from the Long and Short Column Per Cent

1. Aspartic acid 105

2. Alanine 95

3. Arginine

4. Glutamic acid 92

5. Glycine 79

6. Histidine 92

7. Isoleucine

8. Leucine

9. Lysine

10. Proline

11. Phenylalanine

12. Serine 103

13. Homoserine

14. Threonine

15. Tyrosine

16. Valine 
for pressure during renovation of the colurn and readjustment. It is good to add I ml Brij 35 solution to the $100 \mathrm{ml} \mathrm{NaOH}$ to help clean the column. (Hovever, this does not need to be done more than once a month.)

3. Operation of short column (for basic amino acids).The general procedure is the same as that with the long column, but column loading with amino acids should be less than with the long column. Air pressure of two pounds is enough to produce a $25 \mathrm{ml} / \mathrm{hr}$ flow rate. The teraperature used was $32 \pm 1$ C. Elution was witi citrate buffers at pH 4.25 and $5.28(.35 \mathrm{~N} \mathrm{Na}$ ) (100 tube with $\mathrm{pF} 4.25$ then $\mathrm{pH}$ changed to 5.28). The short column also has excellent reproductibility, and recovery is more than 95 per cent for all amino acids.

\section{Colorinetric analysis for the amino acids (63).-} The reagents necessary for color development are prepared as follows: 1) stock $\mathrm{NaCN} 0.01 \mathrm{M}$ (49 $\mathrm{mg}$ per cent); 2) acetate buffer $3 \mathrm{~N}$ pH $5.3270 \mathrm{gm} \mathrm{Na}$ acetate $\left(\mathrm{NaCH}_{3} \mathrm{COO}, 3 \mathrm{H}_{2} \mathrm{O}\right.$ ) plus $50 \mathrm{ml}$ concentrated glacial acetic acid and $200 \mathrm{ml}$ distilied water brought to $750 \mathrm{ml}$ with distilled water. This buffer is very concentrated $(3 \mathbb{N}$ ) and does not need any microbial protecting agent; 3) acetate cyanide, $2 \mathrm{ml}$ of solution one and $98 \mathrm{ml}$ acetate buffer; 4) ninhydrin solution, 3 per cent ninhydrin in methyl cellosolve (ethylene gljcol monomethyl ether). Methyl cellosolve was checked each tine 
before use to make sure it was very low in peroxides. Mo $2 \mathrm{ml}$ of methyl cellosolve in a test tube, $1 \mathrm{ml} 4$ per cent $\mathrm{KI}$ was added, if it was colorless or a very light straw color, the methyl cellosolve was regarded as satisfactory, otherwise it needed to be distilled; 5) diluent: 50 per cent isopropyl or ethyl alcohol in $\mathrm{H}_{2} \mathrm{O}$.

Test tubes collected in the fraction collector were tested for amino acids by addition of $0.5 \mathrm{ml}$ acetate-cyanide (reagent 3) and $0.5 \mathrm{ml}$ ninhyärin (reagent 4) to each tuje. The contents of the tubes were thoroughly mixed by shaking and swirling. The tubes then were placed in boiling water bath (in a rack of 50 tubes) and were allowed to remain there for 15 minutes. The heat supply to the water bath was such that boiling started again shortly after the rack of tubes was placed in the water bath. After 15 minutes, the tubes were taken out of the water bath, and the contents of each were diluted immediately with $5 \mathrm{ml}$ of 50 per cent EtOH (at room temperature). The tubes were then shaken to mix the solutions. After half an hour, allowed for color development, the optical density (O.D.) was read at $570 \mathrm{mu}$ in a Spectronic 20 colorimeter for all amino acids. For proline, the tubes were also read at $440 \mathrm{mu}$. All readings were against a blank of 50 per cent alcohol. An additional 5 or $10 \mathrm{ml}$ of diluent were added to tubes with color intensity above 0.80 O.D. In such cases the resulting O.D. 
values were multiplied by $1.7(7 \mathrm{mI}+5 \mathrm{ml} / 7 \mathrm{mI})$ or 2.4 (7 $\mathrm{ml}+10 \mathrm{ml} / 7 \mathrm{ml}$ ) for correct amino acid concentration. The reagents should not be mixed together unless they are joing to be used immediately, since the resultant solution is unstable and is useless after two hours. The reaction mixture taken from hot water was immediately diluted because pausing for cooling at this step before addition of diluent alcohol produced high backgrouna values. The strean of diluent was always directed at the center of the test tube, to introduce a maximum of air. The diluted reaction mixture should be allowed to cool to room temperature before reading in the Spectronic 20. The color produced is quite stable. After 12 hours there was only a 10 per cent decrease in the color intensities. A standard solution of leucine was always tested with each run to make sure of the efficiency of the reagents.

Color intensities of individual amino acids were plotted against tube number. The area enclosed by the resulting curves was a direct measure of the total amount of the amino acid.

Test tubes for this work must be well matched for light transmission. However, commercially matched tubes were not available so ordinary tubes were examined, and a large matched set was collected. 
Washing of test tubes is important. Used tubes were first rinsed with hot water and then were washed with Fisher Sparkleen detergent in hot water. They were again rinsed in hot water and finally were rinsed two times in aistilled $\mathrm{H}_{2} \mathrm{O}$ and were dried in an oven at $110^{\circ} \mathrm{C}$. Occasionally the tubes were also washed in a dilute $(0.2 \mathrm{~N})$ solution of hydrochloric acid and were then rinsed in distilled water.

\section{G. Protein determination}

For the measurement of total soluble protein, the handing of the plant material for sampling was the same as for the amino acids. Samples for protein determination were prepared in the following steps:

1. A weighed amount of leaves ( 1 to $5 \mathrm{gm}$ ) were rinsed with cold distilled water for a short time.

2. These leaves were homogenized in ice cold condition with a hand tissue homogenizer (in $25 \mathrm{ml}$ distilled $\mathrm{E}_{2} \mathrm{O} / \mathrm{gm}$ leaves) for five minutes.

3. The well homogenized tissue was quickly passed through cheesecloth (ice cold condition). Filtrate was brought to a measured volume at about $25 \mathrm{ml} / \mathrm{gm}$ tissue.

4. Equal amounts of ice cold 5 per cent trichloroacetic acid were added to the filtrate in number 3 above, with shaking, to obtain complete pracipitation of the protein. 
5. The sample was centrifuged for ten minutes at $1000^{X_{G}}$.

6. The precipitate was promptIy washed with acetone to remove chlorophyll and other pimments (20 $\mathrm{ml}$ acetone per gm of tissue).

7. After another ten minutes centrifugation at $1000^{X_{G}}$, the supernatant pigment was removed and saved for total chlorophyll determination.

8. The precipitate, whici was mainly protein, was dissolved in $0.91 \mathrm{~N} \mathrm{NaOH} \mathrm{(40} \mathrm{ml} \mathrm{NaOH} /$ per $1 \mathrm{gm}$ tissue) for protein estimation by the phenol reagent (49).

9. A measured volume of the protein solution (usually 0.25 to $0.5 \mathrm{ml}$ ) was placed in a graduated $10 \mathrm{ml}$ test tube, and $5 \mathrm{ml}$ of a mixture of the following reagent was added to the tube:

Reagent A - $100 \mathrm{ml} 2$ per cent $\mathrm{NaCO}_{3}$ in $1 \mathrm{~N} \mathrm{NaOH}$ Reagent $\mathrm{B}-\mathrm{I} \mathrm{mI} 4$ per cent $\mathrm{Na}$ tartrate in $\mathrm{H}_{2} \mathrm{O}$ Reagent C - I mI 2 per cent $\mathrm{CuSO}_{4}, 5 \mathrm{H}_{2} \mathrm{O}$ in $\mathrm{H}_{2} \mathrm{O}$. (The three reagents must be mixed together shortly before use.) After adition of the reagent the tube was shaken vigorously and was left at room temperature for ten minutes.

10. A volume of $.5 \mathrm{ml}$ of Phenol reagent (Folin-Ciocalteu) was added to the sample tube; the tube was shaken well and was allowed to stand 30 minutes at room temperature. 
11. Preparation of standard curve:

A standard curve was prepared using a solution of bovine serum albumin (amounts ranged from 50 ugm through 500 ugm). The standard curve obtained did not follow Beer's law for high concentrations, so the sample must be low in concentration in order to get an accurate reading. It is very important to be careful not to denature protein during handing; dilute bovine solutior denatures usually very fast. The colored solutions obtained were read in a Beckman D.U. spectrophotometer or Spectronic 20 at wavelength of $750 \mathrm{mu}$. The values presented are usualiy an average of two or three determinations. For determination of total protein we used the method of Iowry (50). This method is basea on the final color formation due to both the Biuret reaction and the Folin reagent (reduction of the phosphomolyhdic-phosphotungstic reagent by the tyrosine and tryptophan in the treated protein). There are two disadvantages to this method: 1) the amount of color yield varies with different proteins. Therefore, it is good only for comparison of the quantity of two proteins of the same nature; 2) the color is not strictly proportional to concentration since for high concentration it does not completely obey Beer's law; thus dilute solutions of protein should be used. Since the color intensity per unit of protein varies with cifferent proteins, there should 
be a correction factor to calculate the absolute amount of the protein in comparison to a standard such as bovine serum albumin. This is when the absolute quantity of a protein needed to be determined, otherwise for determination of the relative protein content of the same plant variety unoer two different growth conditions there is no need for such a factor to be applied. In the research reported here we were more interested in differences (relative values) rather than the absolute quantity. Despite the disadvantages of the Iowry method, there were several advantages, which led us to adopt it. The method is more sensitive and convenient than is the digestion and Nesslerization method. Also, it is 10-20 times more sensitive than the U. V. absorption method of protein determination. It is much less liable to inaccuracy due to turbidity, while it is almost 100 times more sensitive than the Biuret method for low concentrations of proteins.

\section{H. Chemical treatment technicues}

Metabolites were applied as a leaf spray to plants under different temperature conditions. Plants were sprayed every other day until aripping wet. For a better wetting of leaves, surfactant (Tween 20 -0.01 per cent) was added to the metabolite solution. The different metabolite solutions which were the same as those employed by Ketellapper (32), included: 
1. Vitamin B mixture.

2. Vitamin $C$.

3. Nucleosides.

4. Sucrose.

The composition of chemicals (metabolites) sprayed on leaves is shown in Table 4. The control plants were sprayed with water plus surfactant. Chemical treatment continued for several weeks. Plants under both optimum and high temperature condition were treated with these metabolites. Measurement of height, dry weight, Iresh weight and finally flower and fruit formation was carried out to examine the effect of these metabolites. 
TABLE 4

Composition of Metabolite Solutions Sprayed on Leaves

Mixture

1) Vitamin B Mixture

Thiamin

Riboflavin

Ca-pentathenate

Biotin

Pyridaxin

Nicotinic acid

Inositol

Folic acid

2) Riboside Mixture

Adenosine

Guanosine

3) Ascorbic Acid

4) Sucrose Solution

Sucrose

Sulfanilamide
Concentration

$20 \mathrm{mg} / 1$

$5 \mathrm{mg} / 1$

$20 \mathrm{mg} / 1$

$1 \mathrm{mg} / \mathrm{I}$

$20 \mathrm{mg} / 1$

$40 \mathrm{mg} / \mathrm{I}$

$200 \mathrm{mg} / 1$

$5 \mathrm{mg} / 1$

$3 \times 10^{-4} M$

$3 \times 10^{-4} \mathrm{M}$

$1 g / 1$

$1 g / 1$

$125 \mathrm{mg} / 1$ 


\section{SAMPIING AND PHYSIOIOGICAL AGE}

Sampling from plants under different environmental conditions accoraing to their chronological age is not advisable when studying the biochemical effects of one of the environmental variables. Differences in physiological age at a given chronological age soon develop, introducing a second variable which may have pronounced interferning effect on the study of the first variable.

In the experiments with high and low temperature effects, after a short time plants of the same chronological age would not have the same physiological age, since time of flowering and fruit formation would be profoundily affected by the temperature. Thus, there are biochemical changes associated with the stage of maturity while it is biochemical changes due to temperature, at equivalent physiological ages, which we wished to study. Accordingly, we took the following steps to obtain maximum uniformity of plant material and to insure sampling of plants at physiologically equivalent age.

Seeds, and then the young seedlings, were hand-graded to obtain uniform size plants by discarding unusually small or large plants. Samples for extraction were taken from at 
least five plants. The five plants were chosen from a rather large number of plants (usually 60) in a ranòom way (67). To eliminate the problem of physiological age aifferences, a numerical index of vegetative development, the plastochron index of Erickson (12), was determined in each case and samples were taken for analysis at equivalent indices. The period between the initiation of successive leaves as well as the size of leaves are features considered in the plastochron concept. A plastochron is defined by Erickson as the time between corresponding stages of development of successive leaves. (For a corresponding stage of development, it is possible to choose either the initiation, maturation or attainment of a standard iength of leaves.) In our research, which was carried out in climatic controlled chambers, the physiological ages of plants grown at high and optimum temperatures were calculated according to Erickson's formula $(12,13,53,56)$.

$$
\text { P.I. }=n+\frac{\log I(a)-\log _{20}}{\log I_{(a)}-\log I_{(a+1)}}
$$

where:

$\mathrm{n}=$ the serial number of leaves which are equal to or just larger than an arbitrary value, whici is $20 \mathrm{~mm}$ in our experimezt, $I_{(a)}=$ is the length of the highest leas with length equal to or larger than $20 \mathrm{~mm}$, 
$I_{(a+1)}=$ is the length of the next higher leaf smallex than $20 \mathrm{~mm}$ in length,

P.I. = plastochron index.

Usually the P.I. is a good index of the developmental age for a plant which has stable spiral phylotaxy (12). During the vegetative period of growth, the P.I. is linearly related to time. Plotting of P.I. values of each day against time after germination gives almost a straight line and can be used as a good substitute for chronological age. If the length of the leaf a is exactly equal to the arbitrary length value, the plant would have a P.I. equal to $n$, but this does not happen frequently; usually $I_{(a)}$ is more on less than that value. For example, if $I_{(a)}$ equals $25 \mathrm{~mm}$ and $I_{(a+1)}$ equals $17 \mathrm{~mm}$ at a given time, it is clear that the P.I. of the plant is more than $n$ and less than $(n+1)$. In practice, the P.I. calculation is carried out by counting all the leaves that are equal to or larger than $20 \mathrm{~mm}$. Then measurements are made of the length of two successive leaves which respectively are less $I_{(a+1)}$ and just equal to or more than $20 \mathrm{~mm}\left(I_{(a)}\right)$. Therefore, in our example, if $n=15, I_{(a)}=25 \mathrm{~mm}$, and $I_{(a+1)}=17 \mathrm{~mm}$, the P.I. value would be:

$$
\text { P.I. }=15+\frac{\log 25-\log 20}{\log 25-\log 17}=\frac{\log \frac{25}{20}}{\log \frac{25}{17}}=15.58
$$


All samples taken for extraction from plants grown in the two tomperature conditions were taken at such times as to have the same P.I. value \pm 0.2 P.I. units. After the plants passea the vegetative period and reached the reproductive stage of life the plastochron index could not be used any more. For the extracts taken arter flowering started, the time after flower initiation was considered only as the chronological time. Three extracts were taken during the vegetative period, one in the flowering stage and one seven days after flowering when small fruits are formed. In most cases, plants under high temperature conditions did not produce any fruit or at least not any perfect fruit, so they remain for a long time in the vegetative stage and ultimately start rosette type of growth. It is evident that biochemical comparison of this group with the optimum temperature group (which have rruit and are in a perfect reproductive stage) is of little value. That is why further samples were not taken. Fruit formation in one series of plants under optimum condition was inhibited simply by the removal of pistil or ovary with a sharp needle to produce similar physiological conditions in the optimum and high temperature groups. Growth characteristics of this group were compared with that or the high temperature group. 


\section{RESULTS AND DISCUSSION}

\section{Growth Characteristics of Plants Under Optimum and High Temperature Conditions}

\section{A. Elongation (increase in total height)}

The pattern of growth (reight increase) in the relatively heat-sensitive pea variety Greater Progress was quite different at high and optimum temperature conditions (Figures 1 and 2). The plants grown at high temperature grew very rapidly during the first weeks after germination (14 to 19 days after seeds were planted). At optimum temperature, the rate of elongation gradually rose to a maximum at about 19 days after seeảs were planted. The sudden and sharp drop in the rate of elongation at the high and optimum temperature condition coincided approximately with the time that the reserve materials of the seed were exhausted. Fowever, the arop in growth at this stage vas greater at high than at optimum temperature. Flower bud formation usually started about 25 days after planting at the optimum condition and occurrea about three dajs carlien under the high temperature regime. Flowering caused a decline in the rate of stem elongation, and by the time fruit set started, the elongation stopped altogether. At the high temperature condition there 
Fig. 1. Daily height increase of pea plants under two temperature regimes.
(a) early drop in elongation
(b) flowering period
(c) fruit formation occurring
(d) abscission of flowers and immature fruits occurring at the high temperature condition
(e) second flowering period at high temperature condition
(Æ) second absicssion of fruits and flowers 


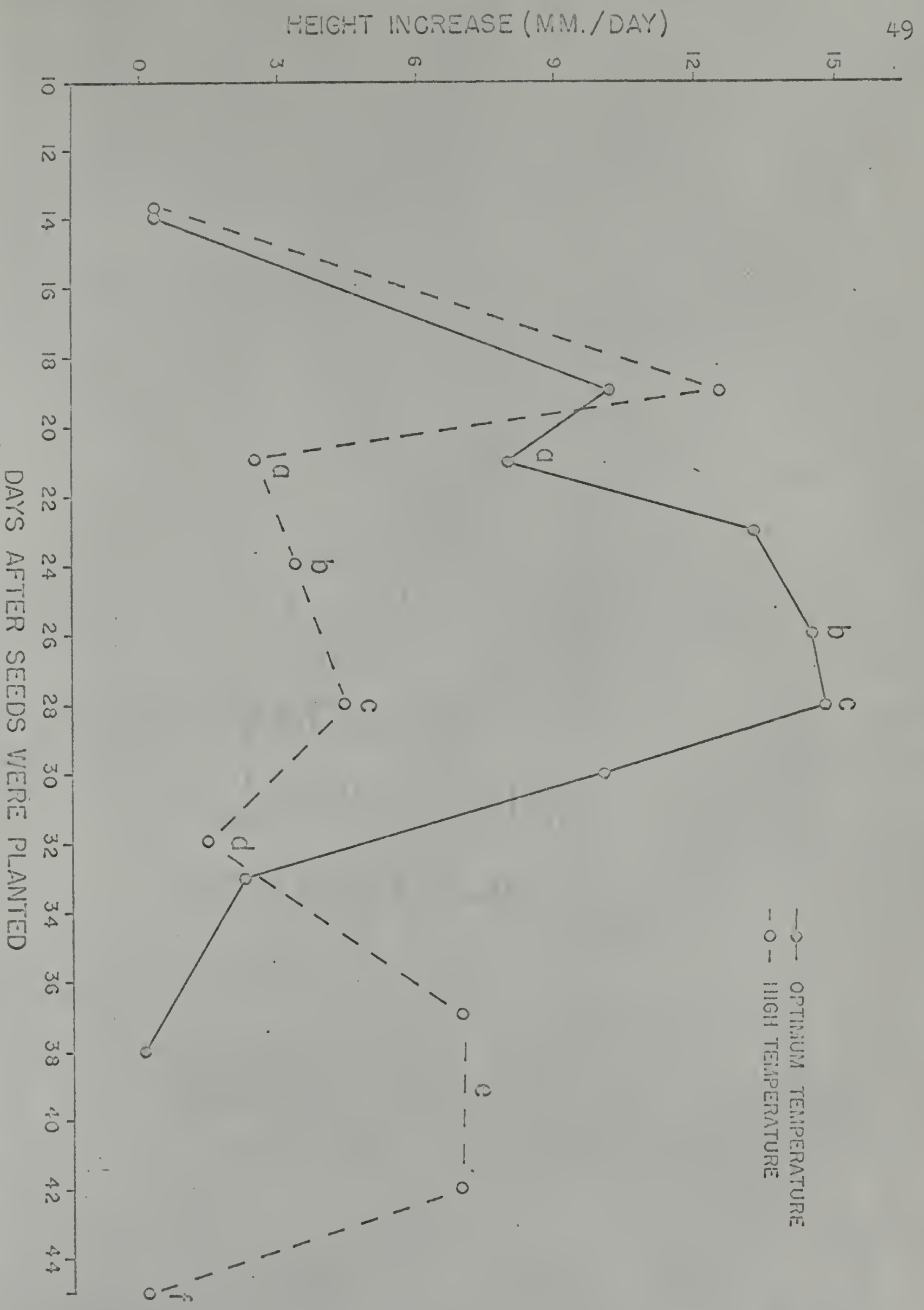

F!C.! 
Fig. 2. Growth (height increase) of the pea plants under high and optimum temperature conditions as compared with the groups of plants which were depistillated (in oxder to stop fruit formation) at the optimum temperature condition. 


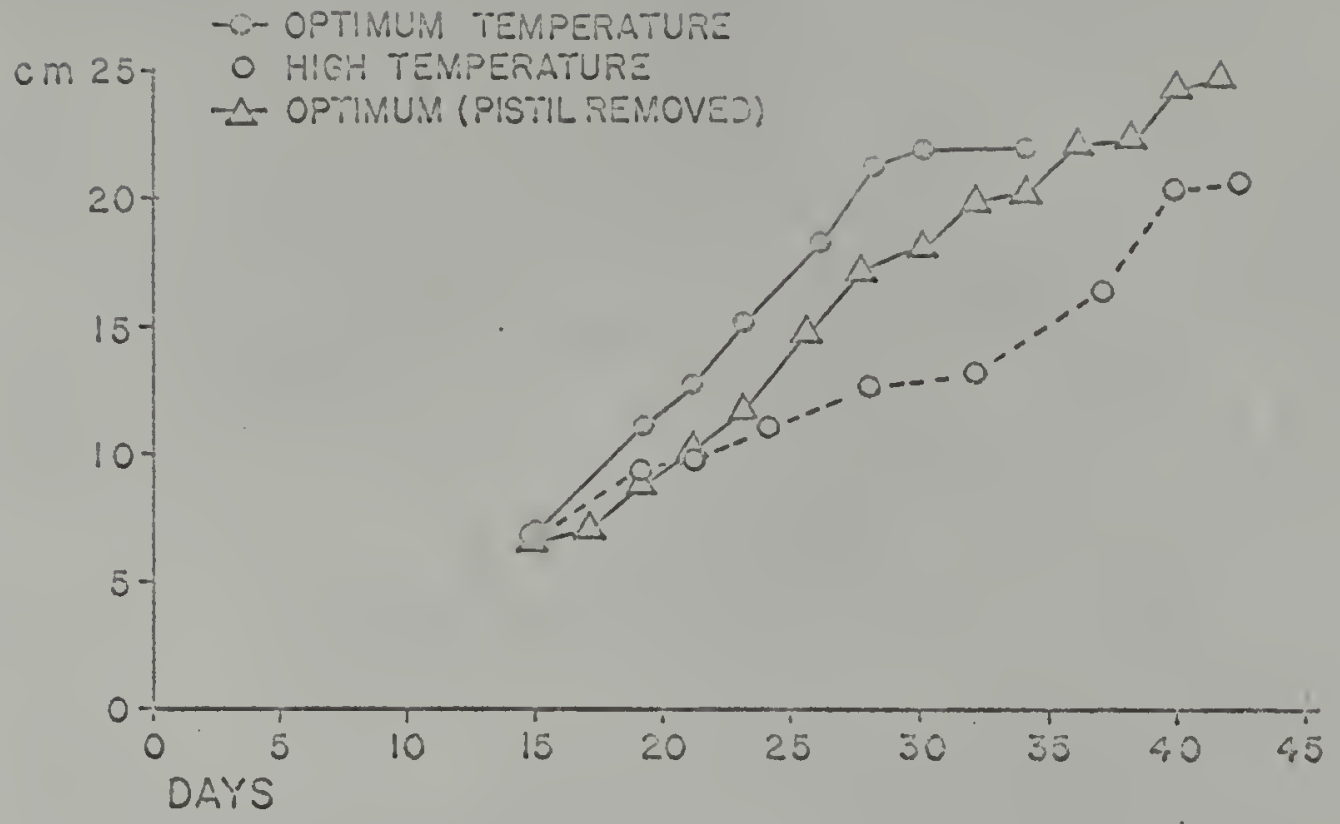

FIG.2 
was a decline in the rate of height increase during the flowering period similar to the optimum temperature condition, but the elongation neven ceased altogether because there was no perfect fruit set at this condition. At high temperature, abscission of the flowers usually occurred; if not, any young fruit that did form abscissed very early in the developmental stage. After the first flowering period stopped without any fruit being formed, the rate of stem elongation of the plant under the high temperature regime again increased. This increase in elongation continued until a second flowering period startec. Since we were interested in studying the efrects of temperature pen se ratier than a possible seconarary effect of flower initiation and abscission, we attempted to produce more comparable plant material by removing the pistils of flowers as they formed in a group of plants at optimum temperature.

The pattem of stem elongation seen after flower initiation in the high temperature series could be obtained also under the optimum temperature condition when the flowers were depistillated in order to stop fruit formation (Figure 3). The main difference in the pattern of growth between the two conditions seen in this experiment was that flowering occurred more often and mucin faster when the pistil was removed by hand at optimum temperature than when the flower and Iruit drop was caused by high temocrature. The increase 
Fig. 3. Daily height increase at optimum temperature conditions (pistil removed).
(a) early drop in elongation
(b) flowering period
(c) fruit set
(d) pistil (or very small fruit) removed
(e) flowering started for second time
(i) removal of pistil or young fruit
(g) flowering started for third time
(h) removal of pistil or young fruit 
HEIGHT INCREASE (MM./DAY)

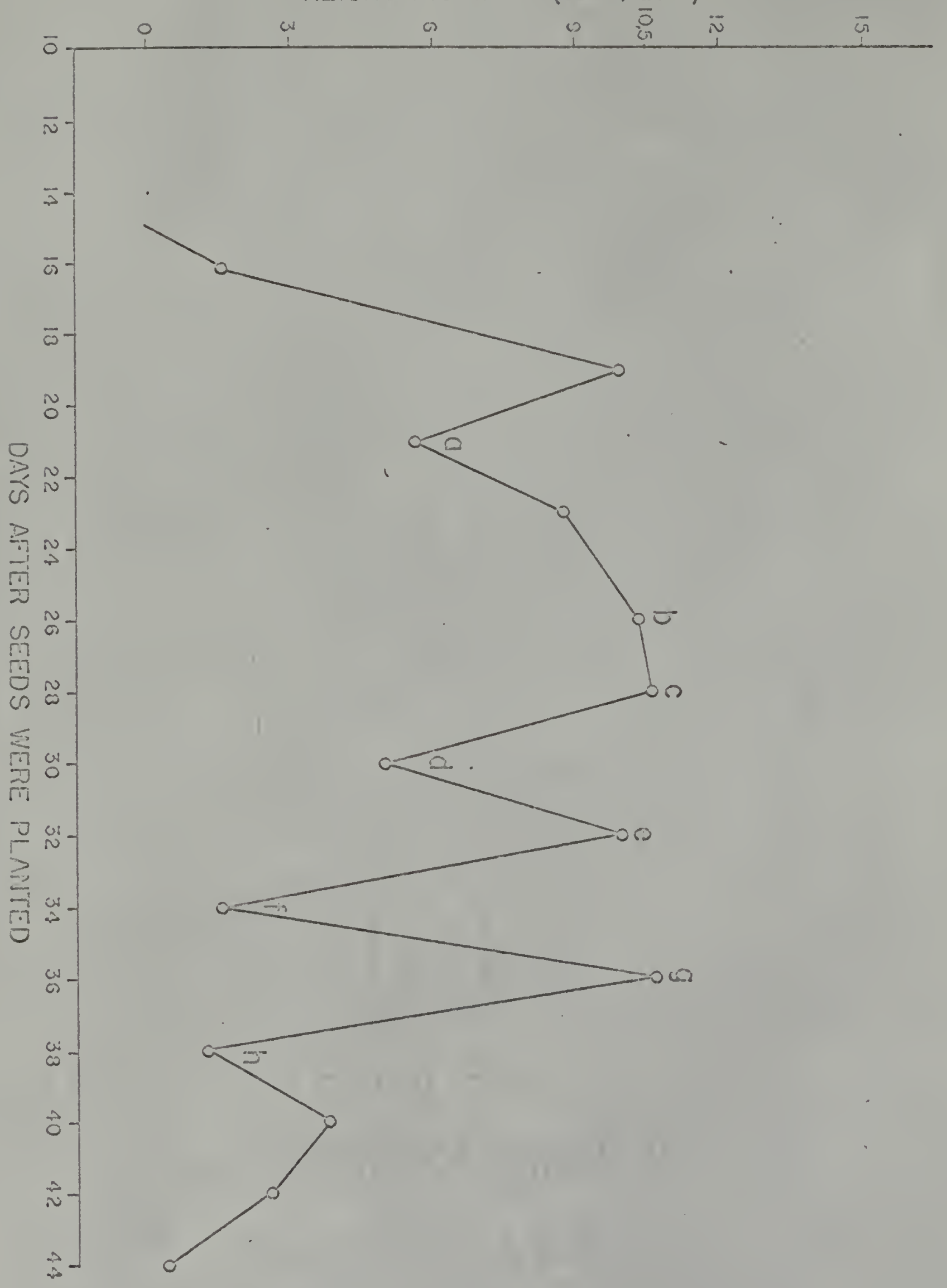

FIG. 
ard cecrease in growth rate was also sharper and Eore Irequent in the cepistillatod, optimun-temperature series. The life span of plants under optinum conditions usually was about two months, while at high tomperature it usually exceeded three months.

To test whether the inhibition of fruit formation, and hence longer period of growth might be due to a failure of pollination, groups of plants grown under the high temperature condition were brought to optimun-temperature for one week during the flowering period. There was no significant improvement as far as formation of perfect iruit was concerned. However, if they were rept for a period longer than one week at optimun-temperature, the fruit set occurred in a normal way. Whese observations eliminate the possibility that inhibition of fruit rormation was due to the simple failure of polinnation at higin temperature. However, this does not indicate whether pollen was viable or not at high tomperature. Of course, high temperatures migit have affected the rate of maturation of flover pistils and stamen so that tiey did not mature at the same time, a process that is likely to kappen in mary self-pollinating plants undor certain environmental conditions. If tho railure oI fruit set at high temperature was due to ceranged maturation of fiower parts directIy caused by the elevated temperature, it would seem cbvious that tise initiation of this derangement occurrod more tran a week prios to pollination. 
A number of the growth studies were repeated with a more heat-resistant variety of pea (var. Wanda) at the same time and under the same growing condition. In contrast to the results with the heat-scusitive variety (var. Greater Progress), there was not very much difference in the growth characteristics of the var. Wanda under the two conditions. Although the number of flowers and total yield was less at righ temperature, there was no problem of flowering and iruit formation as observed in the case of the heat-sensitive variety. (Whe data for this part are not presented in this dissertation.)

E. Fresh weight increase at high and optimum temperature

During the first three weeks after planting the seeas, there was little difference in amount o: rate of increase in fresh wight at the two temperature conaitions (Figure 4). Eowever, three weeks after the seeds were planted the rate of fresh weight increase dipped sharply in the high temperature groug but not until the fourth veel in the plants which wore at optinum-temperature. Later on, after the fifth week of growth, there was an increasc in the rate of fresh weight accumulation at the high temperature condition. This increase occurred aiter the first abscission of flowers, at the time that rate of growth and elongation was increasing at high temperature, wile at optimum-temperature the rate continued to decrease. However, increase in fresh weight vs. 


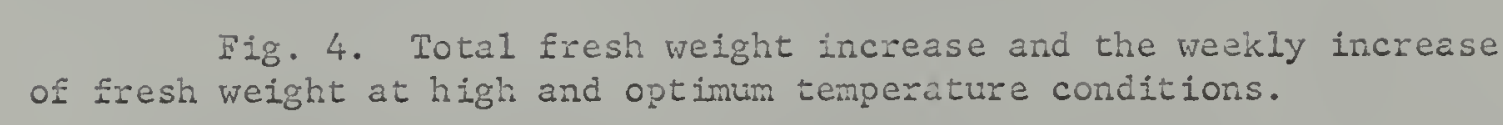




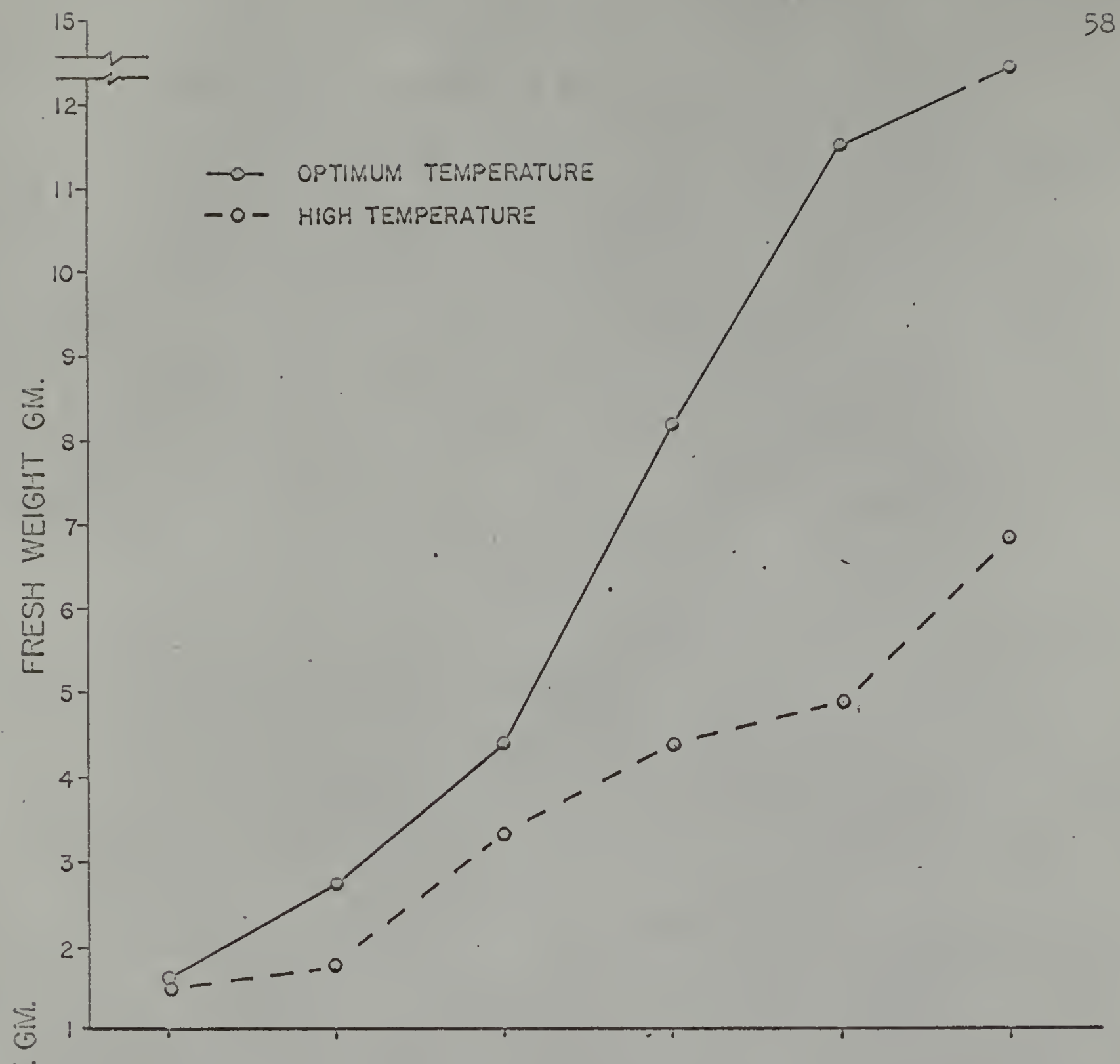

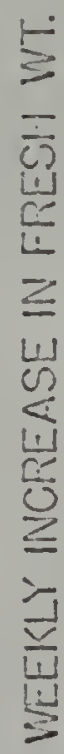

OPTIMUM TEMPERATURE HIGH TEMPERATURE
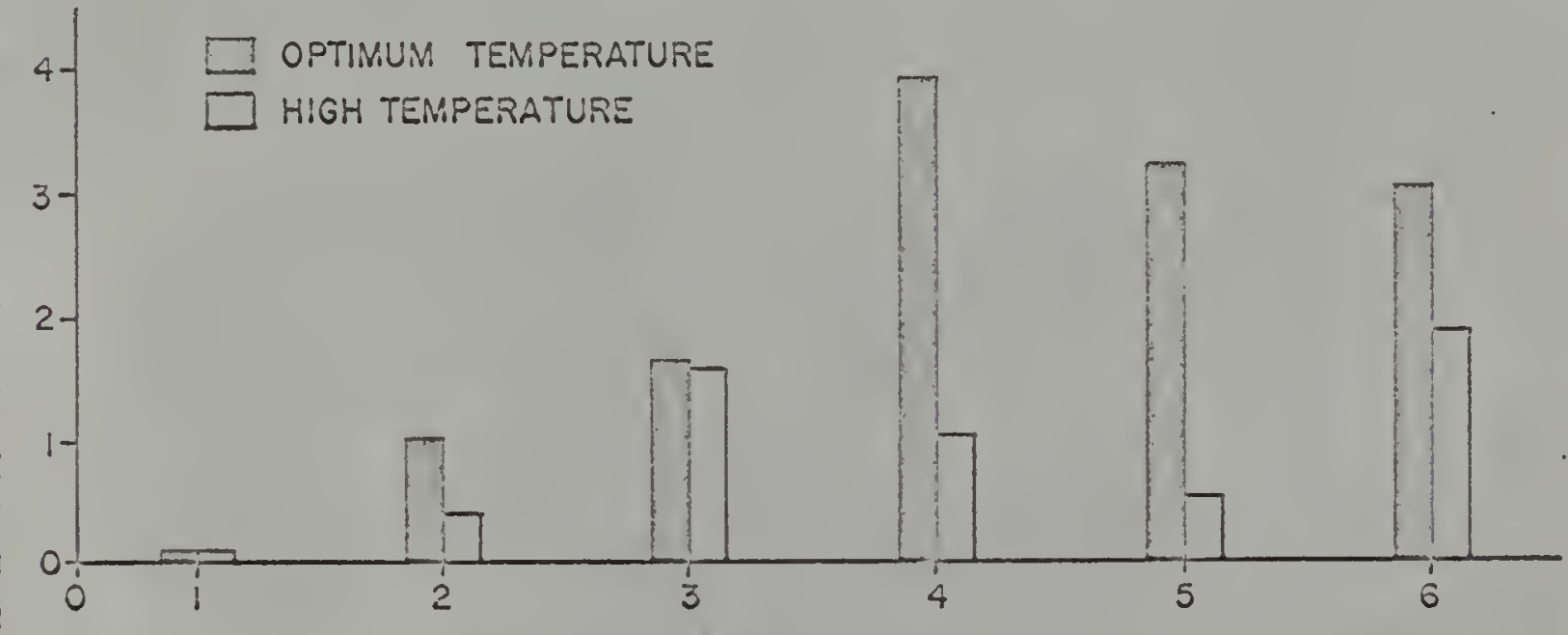

WEEKS AFTER SEEDS WERE PLANTED

FIG. 4 
time had a lower rate at high temperature, and the total fresh weight was much lower at high temperature; part of this decrease rate of fresh weight accumulation at high temperature seems to be due to the abscission of flowers and young fruits which could cause a lowered rate of increase in total fresh weight.

C. Increase in total dry weight at high and optimumtemperature

Total dry weight per plant as well as weekly increase in dry weight were almost the same at the two temperature conditions during the first three weeks of growth, but later the rate of dry weight increase was much faster at optimum conditions (Figure 5). After the fifth week of growth, the rate of dry weight increase dropped at high and optimum conditions simultaneously. However, the rate of increase of dry weight continued to drop at optimum conditions while at high temperature it started to increase again after the sixth week of growth. Here again, this increase was mainly due to rapid vegetative growth that started after the rirst abscission of flowers and fruits occurred at high temperature conditions. The final dry weight per plant (after seven weeks of growth) was almost trice as much at optimumtemperature conditions as at high temperature. 
Fig. 5. Total dry weight increase and the weekly increase of dry weight at high and optimum temperature conditions. 


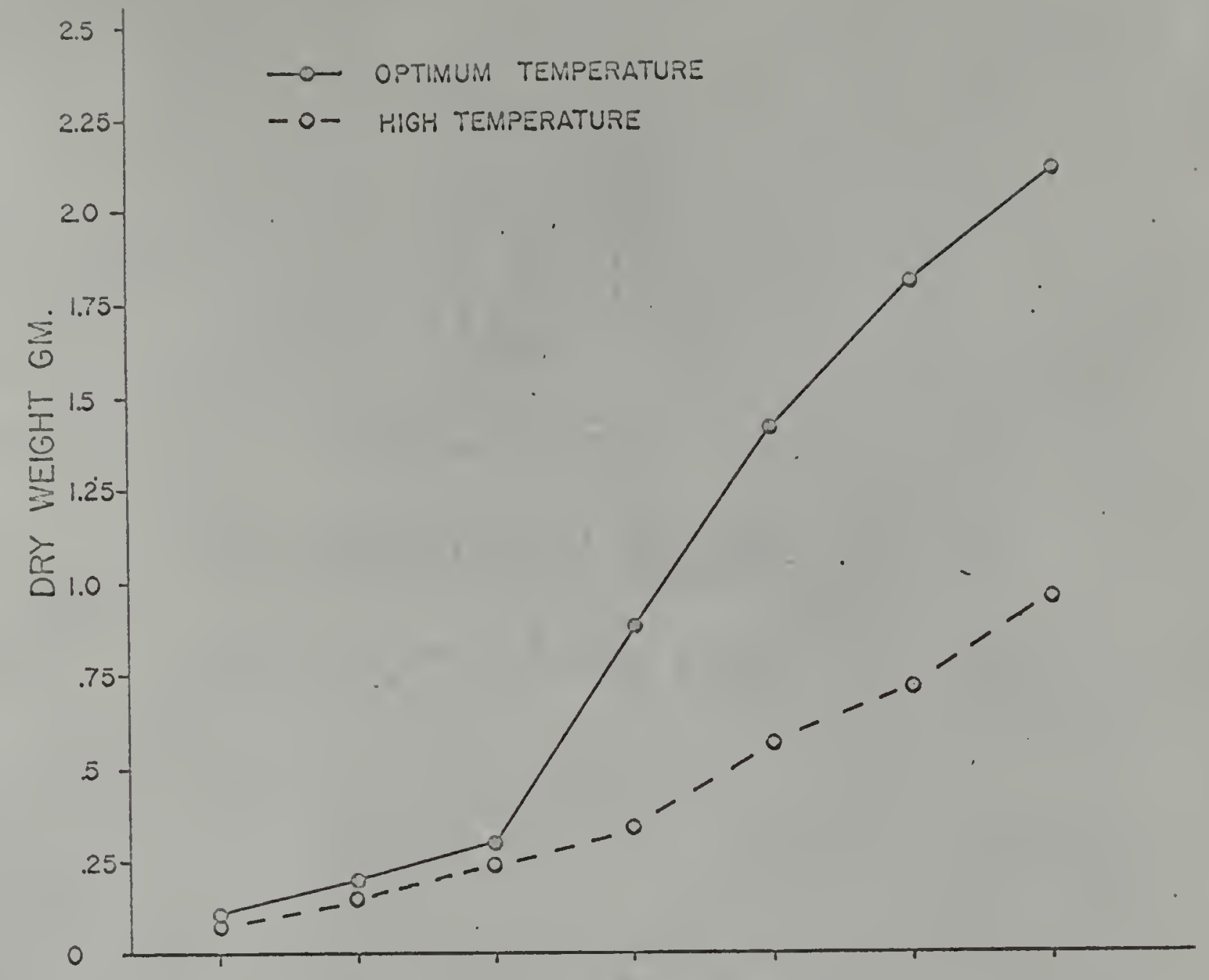

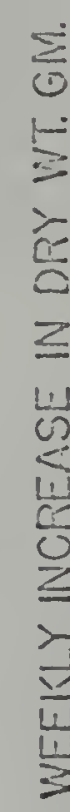

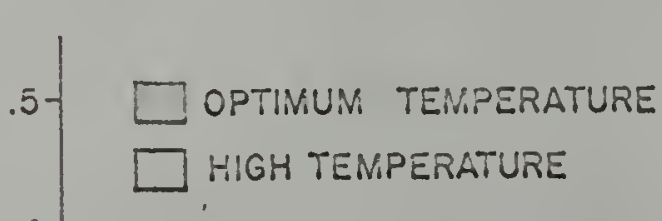

[ $4-1$

$3-$
$2-$
.1
0

$\frac{1}{0}$
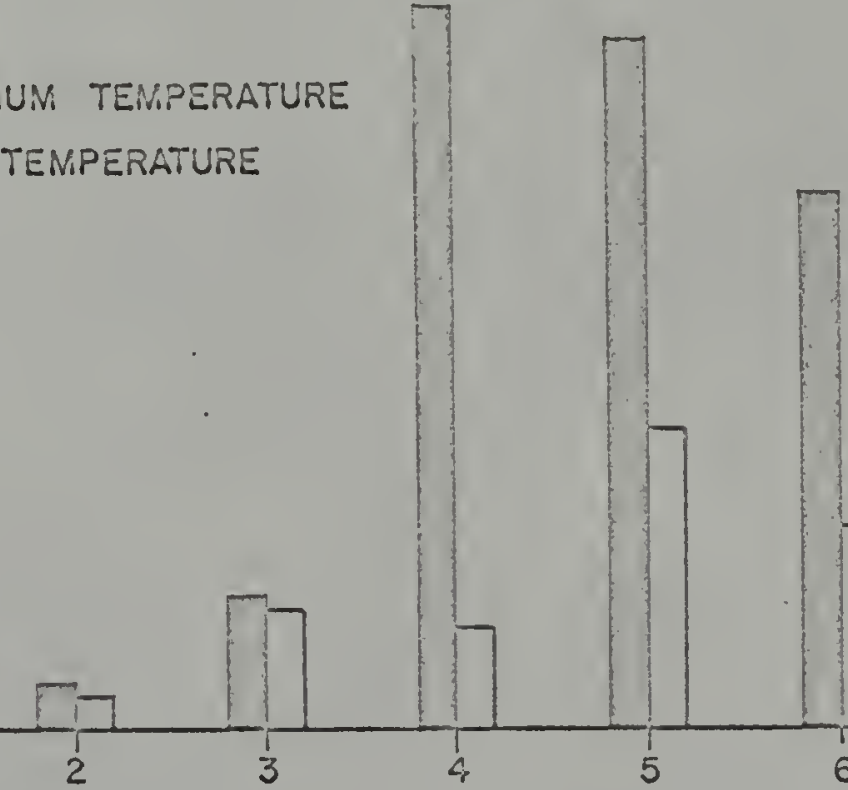

WEEKS AFTER SEEDS WERE PLANTED

F!G.5 


\section{Increase in percent of dry weight}

The percent of dry weight was almost the same at the two conditions, and there was a continuous rise in the percentage of dry weight as the plants became older. After fruit set, however, there was a very rapid rise in the percent dry weight at optimum-temperature conditions, while at high temperature there was a slow rise in percent dry weight.

\section{E. Shoot-root ratio}

The ratio of shoot weight to root weight was almost the same through three weeks of growth at the two temperature conditions (Figure 7). Later the ratio increased at the optimum condition (as fruit formation started) and became much more than at the high temperature condition. The low ratio of shoot to root at this period, in plants grown at high temperature, was partly due to abscission of flowers and fruits. But, after the fifth week of growth, the ratio in the high temperature group started to increase; and finally, by the sixth week the ratio became equal to that of optimum conditions. This increase in shoot-root ratio probably was a result of the spurt in vegetative growth observed at this time in the plants exposed to high temperatures. 
Fig. 6. Increase in per cent dry weight at different stages of growth at optimum and high temperature conditions.

(a) Fruit set occurred in plants grown at optimum temperature conditions, but not in plants grown at high temperature.

Fig. 7. Shoot-root weight ratio versus time.

(a) Ratio increases faster at optimum condition during flowering and early fruit formation period.

(b) Ratio became higher because of fruit formation at the optimum condition. Finally, fast vegetative growth after the first abscission of flowers and fruit at the high temperature condition increases the ratio. 


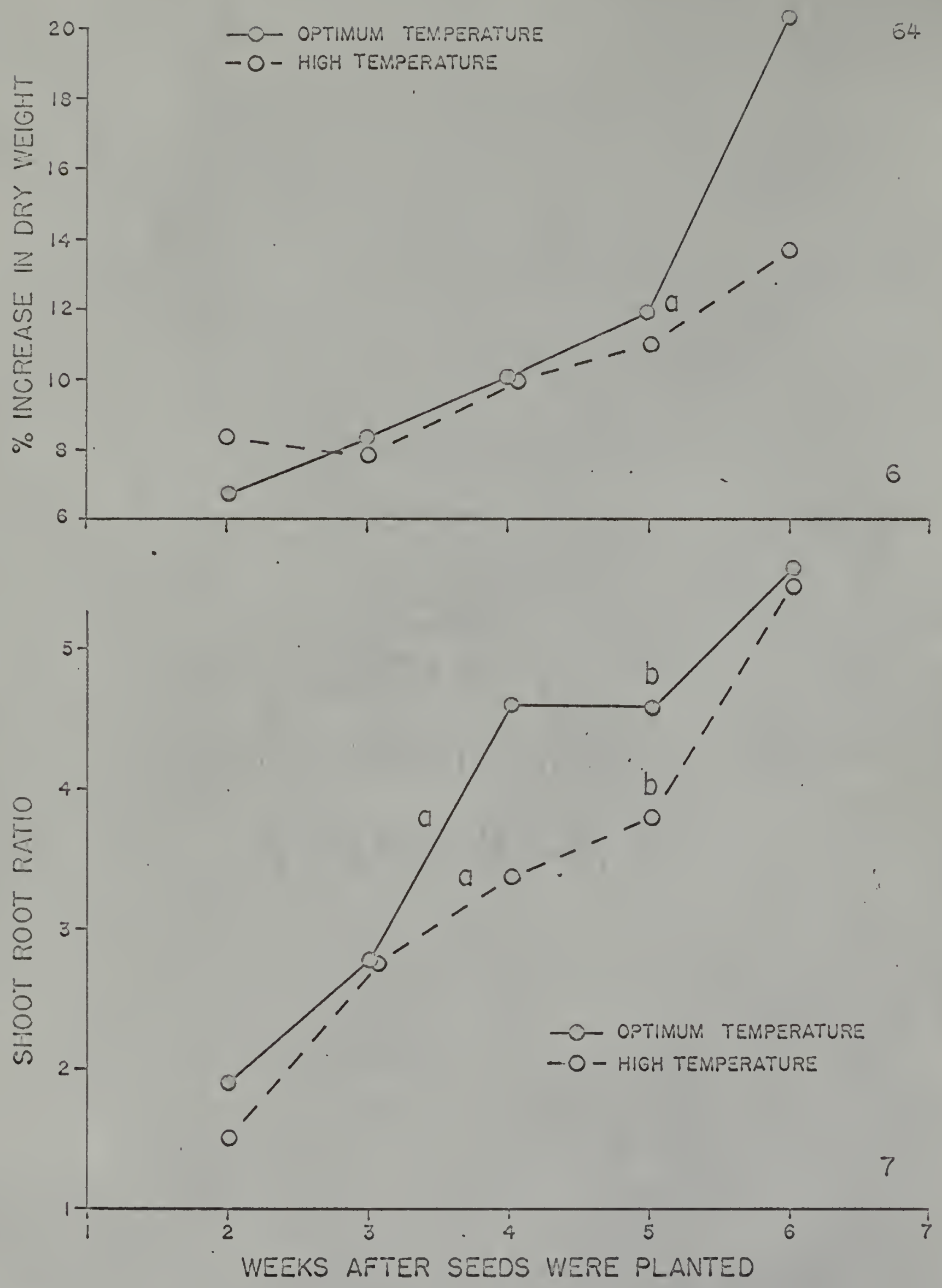

FIG. 6 cnd? 


\section{Amino Acid Analyses of Peas Under Optimum}

\section{and High Temperature Conditions}

\section{A. General}

The results of the quantitative analyses with ionexchange column chromatography of the plant extract for their amino acids are show in Figure 18 and in Tables 5 through 10. Results are expressed in terms of micromoles of amino acid per gram fresh weight. Values for the amino acid quantity present were calculated on the basis of the color yield with ninhydrin of a standard solution of leucine, observed in frequently repeated standard curve determinations. The results in most cases were repeated two or three times to make sure of the reproducibility and consistency of the location of the peaks for each amino acid in the effluent. After reproducibility and consistency of the chromatograms were well established, further analyses of the extracts were carried out only once. After several analyses, it was found that elaborate purification of the plant extracts was not necessary in orcer to make quantitative determination of amino acids. (Efficiency of the column for analyses of amino acids in the partially purified extracts was almost the same as for well-purified extracts.) 
B. Problems in separation and identification of individual amino acids

There was some uncertainty concerning the location or adequacy of resolution of certain peaks in the chromatograms. Careful control of conditions, or additional steps resolved a number of these problems. For example, the location of valine, isoleucine and leucine peaks depended on the time when citrate buffer of pH 3.25 was replaced with the citrate buffer of pi 4.25 .

The asparagine and glutamine peaks normally were combined with each other and serine, making it impossible to determine the quantity of these amino acids. Therefore, determination of the quantity of asparagine, glutamine and serine was carried out by the hydrolysis of the asparagine and glutamine in the extract. For this purpose, the purified plant extracts were hydrolyzed in a solution of $0.1 \mathrm{~N}$ $\mathrm{HCl}$ at $100^{\circ} \mathrm{C}$. for three hours ( $20 \mathrm{ml} \mathrm{HCl}$ for $0.5 \mathrm{ml}$ extract equivalent of $0.5 \mathrm{gm}$ iresh tissue); the hydrolyzed extracts were chromatographed, and the increase in quantity of aspartic and glutamic acid as compared with that of a nonhydrolyzed extract was determined and calculated as asparagine and glutamine. Serine determination after hydrolysis was also carried out. In all cases, the amount of asparagine was much more than glutamine. Synthetic mixtures of a known quantity of serine, asparagine and 
glutamine were hydrolyzed in the same way and then chromatographed; the results obtained showed that there was an 8 per cent loss due to hydrolysis and handing of the sample. Therefore, values in the hydrolyzed extracts vere corrected for this loss. In analyses of extracts, it was observed that a number of peaks appeared early before the aspartic acid, which, on the basis of its acidity, one would expect to find as the first peak. These early peaks were found to be mainly peptides, soluble in 80 per cent ethanol. Treatment of extracts with $0.1 \mathrm{~N}$ ECI calised the disappearance of all of these peaks except one. The peak immediately before the aspartic acid (the one that did not aisappear on hydrolysis) appeared to be methionine sulfoxide, according to the location of a known sample of methionine sulfoxide in a chromatogram of a synthetic mixture of amino acids. Assignment of methionine sulfoxide to this peak is consistent with the results of Iawrence (43) in similar analyses. Methionine is well known as an unstable amino acid that oxidizes readily to methionine sulfoxide curing handing and storage of plant extract. A hyärolysis method was also carried out for exact determination of the quantity of methionine sulfoxide, because the peak of methionine sulfoxide in unhydrolyzed samples coincided with one of the most abundant alcohol-soluble peptides of pea seedlings, known as -glutamyl alanine (74). Finally, the total amount of 
peptides was calculated by suming all the peaks appearing before aspartic acid (minus methionine sulfoxide). Proline determination was not satisfactory in most cases. Usually the large size of the glutamic acid peak, which appeared just before the proline peak, caused tine two of them to overlap. The low optical density yield of proline per umole (even at $440 \mathrm{mu}$ wavelength) with ninhyarin reagent and also the low content of proline in the extract, made proline contamination an insignificant factor in the glutamic acid analysis. However, in most cases these same factors made it impossible to obtain quantitative data for proline in the extracts. There was one peak (designated as unknown A) which emerged immediately after proline and before glycine. This peak became larger in the high temperature condition during the flowering period. We did not have sufficient material to carry out tests to establish the identity of the substance giving this peak. However, the peak is in the position to be expected for $\alpha$-aminoadipic acid, known to be a constituent of pea plants $(43,74)$. The glycine peak usually was low and coinciaed in part with some very small interfering peaks. The values presented for glycine are the average of two determinations on each sample. It was necessary to use a certain amount of juagment as to what constituted the true shape of the glycine curve. Accordingly, the precision and accuracy is not as good for glycine as for most of the other amino acids. 
Q. Weekly changes in amino acià content at high and ootimum tomonatures

1. Pirst period or sarpling-Rocults are presonted in Table 5 and Figurele for the total alcohol solubie (free) amino acias content of leaves (um/gri f. wt.) of peas, one weel after seeds were planted (approximately three days after germination, when no fully expanded leaves were present). The araunt of total free anino acid in leaves of the high temperature plants was much greater ( 1.7 times) than in the optimum temperature plants. The amount of each inciviaual amino acid is show in rable 5. This early time in the life of the pea plant, one should remember, is a period of active hyarolysis and utilization of reserve proteins of the seed, as rell as a period of synthesis of new proteins in the aeveloping seedling. Hot unexpectedly, amides were presext in very high amcunts at both temperature conditions. Fowever, the total amides (asparagine plus glutamine) at high temperature were almost 2.5 times higher than at the optimum temperature concition. Nore amino acia and especially more arice formation at high temperature coula possioly be die to more rapia protein breakdora and faster growth at high temperature auring the first week of growth. The total peptides content, homoserine and also methionine sulfoxide, in both extracts were highe: in the first week than at any other time. In contrast, the amount of isoleucine and leucine was 
TABTE 5

Amino Acid Content of Leaves - First Period of Sampling

\begin{tabular}{|c|c|c|c|}
\hline Amino acid & $\begin{array}{l}\text { WN per } \\
\text { Te } \\
\text { Optimum }\end{array}$ & $\begin{array}{c}\text { weight } \\
\text { High }\end{array}$ & Ratio \\
\hline Methionine sulfoxide & 2.72 & 3.24 & 1.20 \\
\hline Aspartic acid & 2.96 & 2.04 & 0.69 \\
\hline Serine & 2.85 & 3.26 & 1.14 \\
\hline Asparagine & 5.00 & 15.9 & 3.18 \\
\hline Glutamine & 2.10 & 6.34 & 3.01 \\
\hline Threonine & 0.34 & 0.47 & 1.38 \\
\hline Homoserine & 1.43 & 4.23 & 2.95 \\
\hline Glutamic acid & 3.27 & 4.95 & 1.51 \\
\hline Unknown A & 0.61 & 0.82 & 1.34 \\
\hline Glycine & 0.96 & 0.48 & 0.50 \\
\hline Alanine & 1.82 & 2.12 & 1.16 \\
\hline Valine & 0.77 & 0.98 & 1.27 \\
\hline Leucine & Trace & Trace & -- \\
\hline Isoleucine & Trace & Trace & -- \\
\hline Peptide & 5.60 & 6.20 & 1.11 \\
\hline
\end{tabular}


low in the first week of growth. There was not a sufficient amount of extract from these young and small plants to permit measurements of the basic amino acias.

2. Second period of samplixg.-Samples vere taken from a group of plants 14 days after planting at optimum and 13 days at nigh temperature (with P.I. values very close to each other).

a. Amino acid of leaves. The amount of amino acia in the extract of high temperature plants was almost three times higher than optimum temperature plants. However, at both conditions the amount of amino acids was less than the previous sample which was taken about a week earlier. Comparison of the incividual amino acids in the second sampling period showed that the most outstanding difference between the two extracts was the presence of a rather large amount of amides in the high temperature plants, while the amide content of the optimum temperature plants was quite low. If amides were not included in the total amino acid content of the high temperature plants, then the total amount of amino acids in the high temperature plants would be two times higher than at optimum temperature conditions. The high amide content at the high temperature condition could have been due to further proteolysis and metabolism of seed proteins (which caused amide formation as an ammonia detoxifying mechanism). On the other hand, the 
high amount of amides and total amino acids could have resulted from a lower protein synthesis at the high temperature condition, resulting in a larger anino acid pool (I).

Methionine sulfoxide and peptide content at high temperature was also much higher than at the optimum temperature. In general, all the other amino acids at high temperature were in a substantially higher amount. The peak of unknown A was very low (trace) in extracts of plants grown under optimum conditions while it was high in the high temperature extract. The results of analyses for this period of sampling are shown in Table 6 and Figure 8. b. Amino acid content of roots. Since there was a very large difference in the total amount of amino acids of leaves at the tro conditions in the second period samples, an extract from the roots at this stage of growth was analyzed, to study the differences in amino acids in the other parts of the plants as corpared with leaves (Table $?$ and Figure 9). Like the leaves, total amino acid content of roots was higher (about 2.5 times) at high temperature than at optimum temperature. In general, however, the pattern of amino acids in roots was somewhat different from that observed in leaves of the same plants. At both temperatures the amount of homoserine was much higher in roots, although it was almost three times higher in the extract from plants grown at high than at optimum temperature. Homoserine 
TABLE 6

Amino Acid Content of Leaves - Second Period of Sampling

\begin{tabular}{|c|c|c|c|}
\hline Amino acid & $\begin{array}{l}\text { LM per g } \\
\text { Te } \\
\text { Optimum }\end{array}$ & $\begin{array}{c}\text { weight } \\
\text { High }\end{array}$ & Ratio \\
\hline Methionine sulfoxide & 0.08 & 2.05 & 25.60 \\
\hline Aspartic acid & 2.22 & 3.52 & 1.58 \\
\hline Threonine & 0.25 & 0.49 & 1.96 \\
\hline Serine & 0.80 & 2.30 & 2.87 \\
\hline Asparagine & 1.10 & 6.54 & 5.94 \\
\hline Glutamine & 0.55 & 2.82 & 5.12 \\
\hline Homoserine & 0.81 & 1.57 & 1.93 \\
\hline Giutamic acid & 1.33 & 3.83 & 2.88 \\
\hline Proline & Present & Trace & -- \\
\hline Unknown A & Trace & 0.29 & -- \\
\hline Glycine & 0.13 & 0.14 & 1.08 \\
\hline Alanine & 0.90 & 1.90 & 2.11 \\
\hline Valine & 0.27 & 0.63 & 2.33 \\
\hline Isoieucine & 0.23 & 0.32 & 1.39 \\
\hline Leucine & 0.13 & 0.48 & 3.69 \\
\hline $\begin{array}{l}\text { Tyrosine plus } \\
\text { phenylalanine }\end{array}$ & 0.65 & 0.51 & 0.78 \\
\hline$\gamma$-aminobutyric acid & 0.33 & 0.97 & 2.93 \\
\hline Lys ine & 0.48 & 0.24 & 0.50 \\
\hline Histidine & 0.96 & 1.37 & 1.42 \\
\hline Arginine & 0.33 & 0.84 & 2.57 \\
\hline Peptides & Trace & 1.50 & -- \\
\hline
\end{tabular}


Fig. 8. Chromatograms comparing amino acid constituents of leaves of pea plants under optimum and high temperature conditions. (Second period of sampling.) The upper chromatogram is from $0.5 \mathrm{gm}$ of leaves at optimum temperature, but the lower one is from $0.25 \mathrm{gm}$ of leaves at high temperature. 

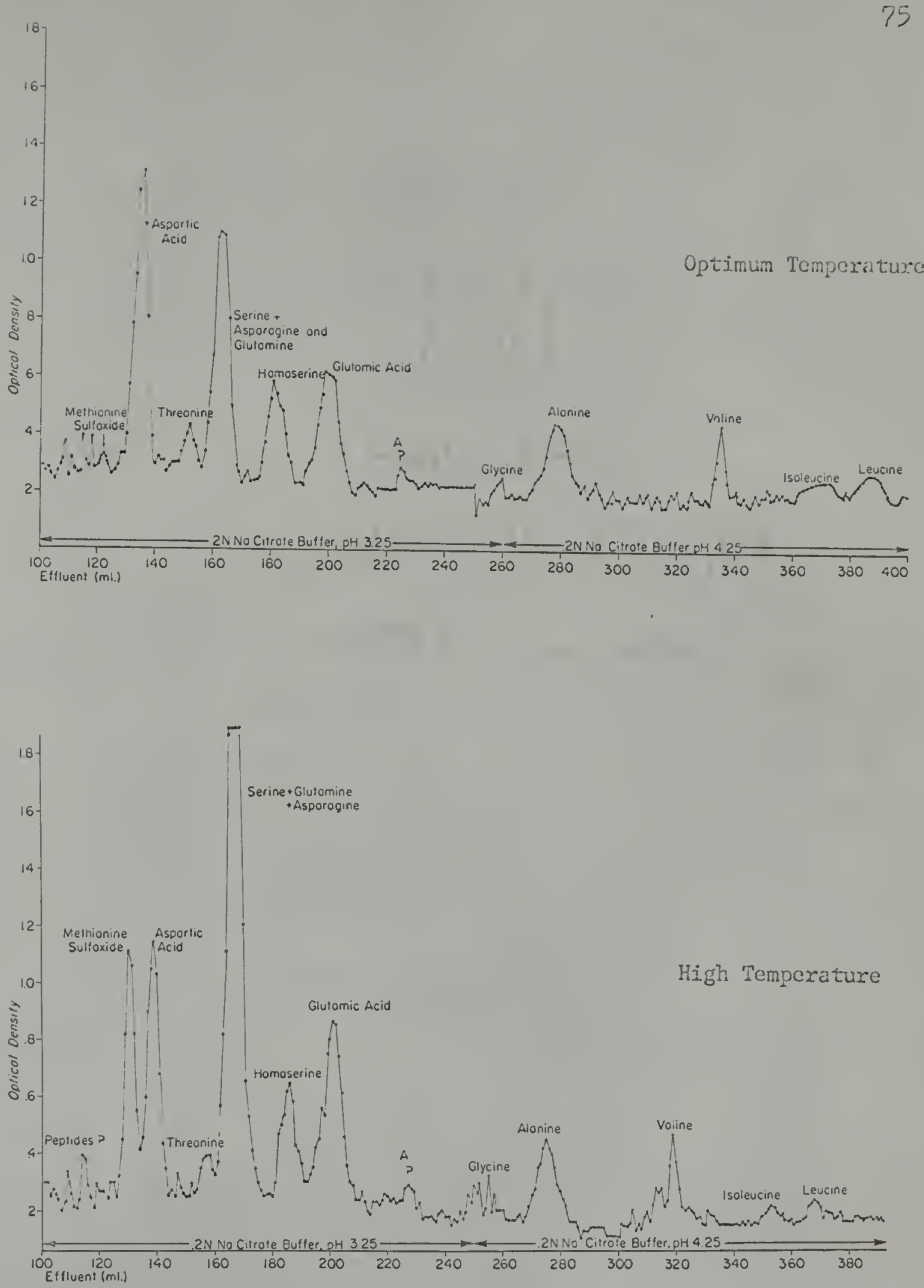

FIG. $\delta$ 
TABIE 7

Amino Acid Content of Root - Second Period of Sampling

$\mu \mathrm{M}$ per gram fresh weight

Temperature

Amino acid

Optimum

High

Ratio

Nethionine sulfoxide

1.17

2.05

1.75

Aspartic acid

0.69

1.13

1.63

Threonine

0.37

0.57

1.54

Serine

0.58

1.12

1.93

Asparagine

1.47

3.20

2.17

Glutamine

1.01

2.05

2.02

Homoserine

11.37

30.12

2.66

Glutamic acid

0.77

1.07

1.39

Proline

Trace

Trace

Unknown A

0.41

0.73

1.78

Glycine

Trace

0.48

Alanine

0.56

1.03

1.82

Valine

0.45

0.50

1.11

Isoleucine

Trace

Trace

Leucine

Trace

Irace

Tyrosine plus phenylalanine

Trace

0.11

$\gamma$-aminobutyric acid

$$
0.16
$$

0.41

2.56

Iysine

Trace

Trace

Histidine

0.25

0.51 


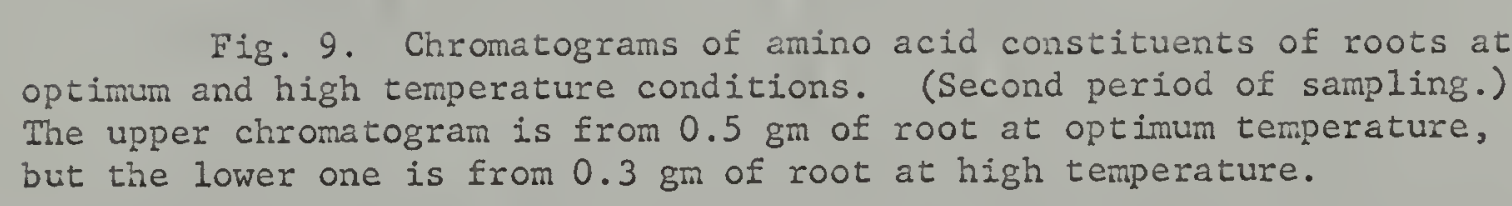



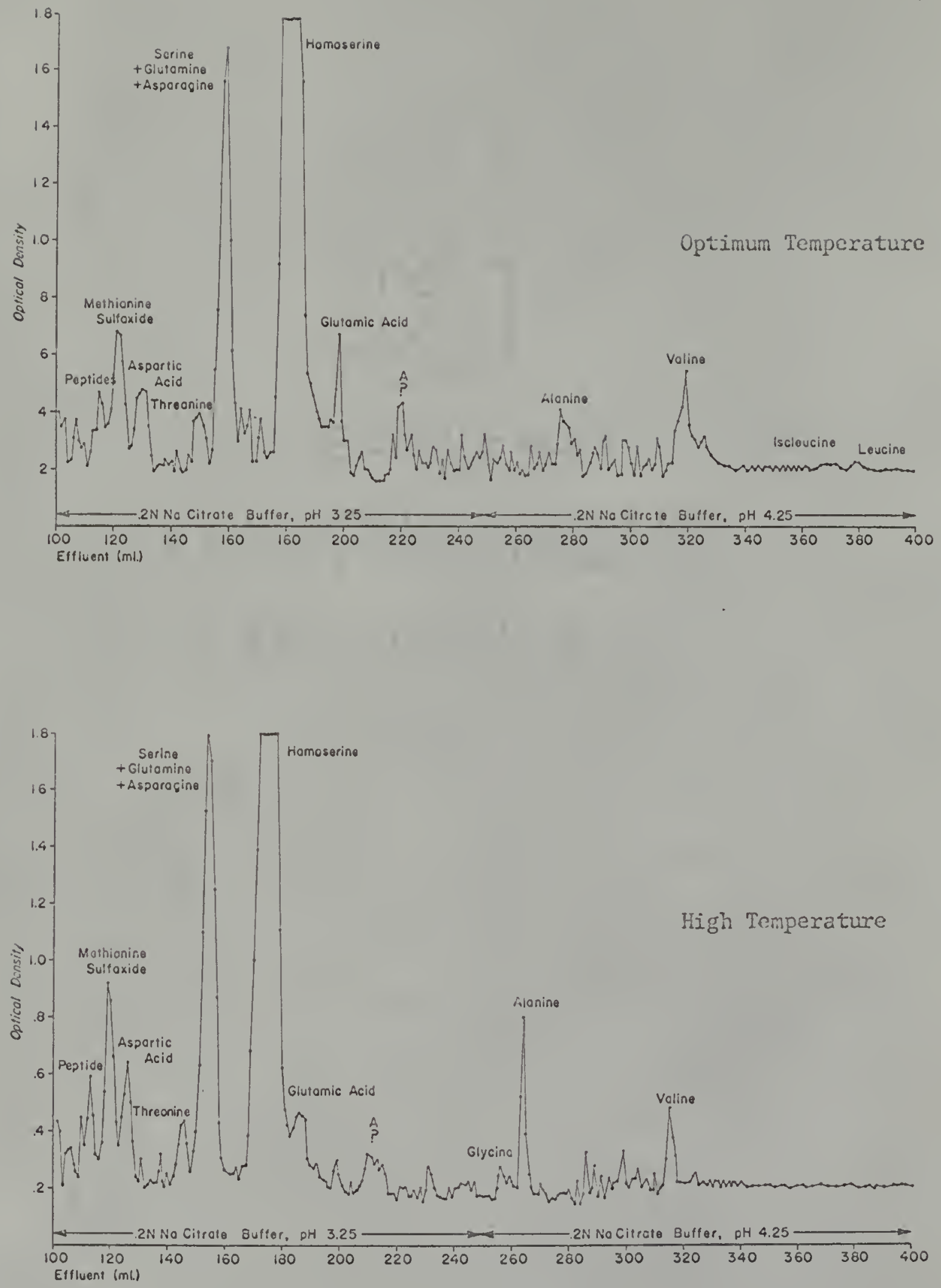

FIG. 9 
is not a protein amino acid although it is known to be an intermediate between aspartic acid and threonine. The high homoserine content in roots of Ieguminosae has been a subject of considerable research and discussion by Virtanen and Sasaoka $(64,76)$. They showed homoserine is absent in seeds but that it is synthesized during germination. The amide content in roots also was much more (three times) at high temperature than at the optimum temperature. Methionine sulfoxide also was about two times higher than at optimum temperature. It will be recalled that similar results for amide and methionine sulfoxide content were observed in leaves.

3. Third period of sampling.-This sample was taken from plants 20 days after planting at high temperature and 22 days after planting at the optimum temperature conaition (with P.I. values very close to each other). The plants were almost in their maximum vegetative growth and a few days away from flowering. Tine total amino acids of leaves from plants grown at high temperature were two-thirds of the previous ( 13 days) sample, while at optimum conditions there was a rise (by 1.4 times) in total amino acias. In this sample, the total amino acids at high temperature were a little more than at the optimum temperature (the ratio was 19:16). This situation, which was quite different from that observed in the previous (second) sampling period, can be 
interpreted as being due largely to two processes: 1) a faster rate of respiration at the higi temperature, which would deplete the seed reserves more rapidly than at the optimum temperature; 2) a faster rate of organic matter production by photosynthesis at the optimum condition. The photosynthetic system is probably more efficient in the plants grown at optimum temperature (as the leaves are larger and they have more chlorophyll). These factors could have caused the increase in amino acids of the optimum temperature plants, while at the same time, caused a decrease since the previous sampling period in amino acid content of plants at the high temperature condition. The pattern of amino acids was more similar at the two temperature conaitions in this sampling period than at any other

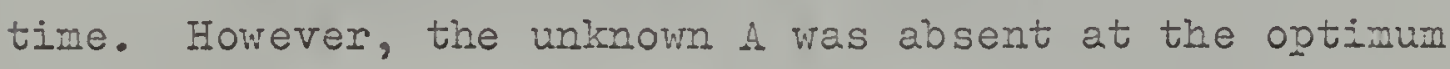
condition while it was quite a large peak at the high temperature condition. Total amide content, also, was very similar at the two temperature conditions. The results are shown in Table 8 and Figure 10.

4. Fourth period of sampling.-Samples were taken when the plants were in the full flowering stage (three days after first flower bud formation). The high temperature plants were 27 days post-planting while plants at the optimum condition were 29 days. The P.I. values were nearly identical for the two groups of plants. Total amino acids of leaves 
TABLE 8

Anino Acid Content of Leaves - Third Period of Sampling

\begin{tabular}{|c|c|c|c|}
\hline \multirow[b]{2}{*}{ Amino acid } & \multicolumn{2}{|c|}{$\begin{array}{l}\text { WM per gram fresh weight } \\
\text { Temperature }\end{array}$} & \multirow[b]{2}{*}{ Ratio } \\
\hline & Ontimum & High & \\
\hline Methionine sulfoxide & 0.45 & 1.02 & 2.26 \\
\hline Aspartic acid & 1.94 & 2.53 & 1.30 \\
\hline Threonine & 0.41 & 0.50 & 1.22 \\
\hline Serine & 2.00 & 1.66 & 0.83 \\
\hline Asparagine & 2.09 & 2.21 & 1.05 \\
\hline Glutamine & 0.94 & 1.19 & 1.26 \\
\hline Homoserine & 0.97 & 1.34 & 1.38 \\
\hline Glutamic acid & 3.17 & 4.13 & 1.30 \\
\hline Proline & Present & Present & -- \\
\hline Unknown A & -- & 0.31 & -- \\
\hline Glycine & Trace & 0.18 & -- \\
\hline Alanine & 2.24 & 1.58 & 0.70 \\
\hline Valine & 0.37 & 0.50 & 1.35 \\
\hline Isoleucine & 0.23 & 0.11 & 0.47 \\
\hline Leucine & 0.27 & 0.13 & 0.48 \\
\hline $\begin{array}{l}\text { Tyrosine plus } \\
\text { phenylalanine }\end{array}$ & 0.20 & 0.35 & 1.75 \\
\hline$\gamma$-aminobutyric acid & 0.49 & 0.51 & 1.04 \\
\hline Lysine & 0.21 & 0.23 & 1.09 \\
\hline Histidine & 0.10 & 0.20 & 2.00 \\
\hline Arginine & Trace & 0.35 & -- \\
\hline Peptides & 0.69 & 0.88 & 1.27 \\
\hline
\end{tabular}




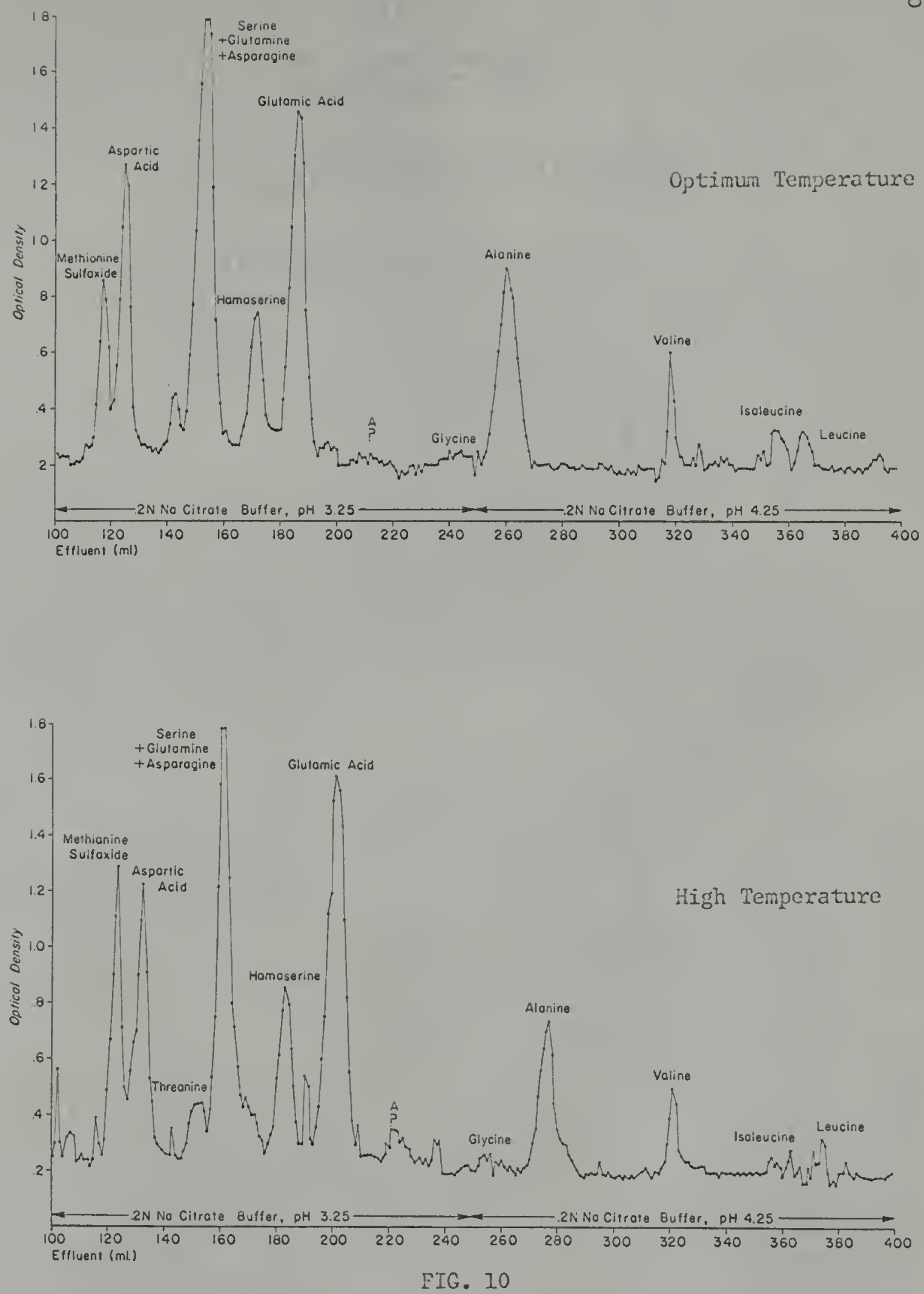
at the optimum condition showed a significant decrease while at the high tempenature condition the total amino acids did not change since the previous sampling period. The ratio of total amino acids of high to optimura temperature was $21: 13=$ 1.6. The amounts of methionine sulfoxide and also total amide content at the optimum condition showed a sharp decrease since the last sampling period. Total amide in the plants grown at optimum temperature was one-sixth of those at the high temperature (Table 9 and Figure 11). The unknown A increased at high temperature, while it was absent at the optimum temperature condition. There was a substantial increase in homoserine content at both conditions. Iysine was very low (trace) at high temperature while histidine was very low at the optimum temperature condition.

5. Fifth period of sampling.-Samples were taken from plants one week after their full flowering period (one week after the previous sample). Plants under optimutemperature had set small fruits while very few if any fruit could be observed on the high temperature plants. There was little change in total amino acid content of the plants under inigh temperature conditions, while there was a considerable decrease at the optimum temperature condition. Total amino acid content in the high temperature plants was twice that under optimum conditions. There was a decrease of amide, such that just a trace was left at the optimum condition 
TABLE 9

Amino Acid Content of Leaves - Fourth Period of Sampling

\begin{tabular}{|c|c|c|c|}
\hline Amino acid & $\begin{array}{r}\text { per } g \\
\text { I } \\
\text { Cotimum }\end{array}$ & $\begin{array}{l}\text { weight } \\
\text { High } \\
\end{array}$ & Ratio \\
\hline Methionine sulfoxide & 0.40 & 0.91 & 2.27 \\
\hline Aspartic acid & 1.05 & 1.90 & 1.86 \\
\hline Threonine & 0.41 & 0.34 & 0.82 \\
\hline Serine & 1.20 & 1.43 & 1.19 \\
\hline Asparagine & 0.29 & 2.05 & 7.06 \\
\hline Glutamine & 0.10 & 0.50 & 5.00 \\
\hline Homoserine & 2.63 & 4.87 & 1.85 \\
\hline Glutamic acid & 2.53 & 3.27 & 1.29 \\
\hline Proline & Trace & Trace & -- \\
\hline Unknown A & -- & 0.32 & -- \\
\hline Glycine & 0.14 & 0.11 & 0.78 \\
\hline Alanine & 1.85 & 2.42 & 1.31 \\
\hline Valine & 0.57 & 0.57 & 1.00 \\
\hline Isoleucine & 0.13 & 0.28 & 2.15 \\
\hline Leucine & 0.12 & 0.22 & 1.83 \\
\hline $\begin{array}{l}\text { Tyrosine plus } \\
\text { phenylalanine }\end{array}$ & 0.27 & 0.44 & 1.62 \\
\hline$\gamma$-aminobutyric acid & 0.63 & 1.14 & 2.80 \\
\hline Iysine & 0.20 & Trace & -- \\
\hline Histidine & Trace & 0.33 & -- \\
\hline Arginine & 0.38 & 0.16 & 0.42 \\
\hline
\end{tabular}


Fig. 11. Chromatograms of amino acid constituents of leaves at optimum and high temperature. (Fourth period of sampling.) 

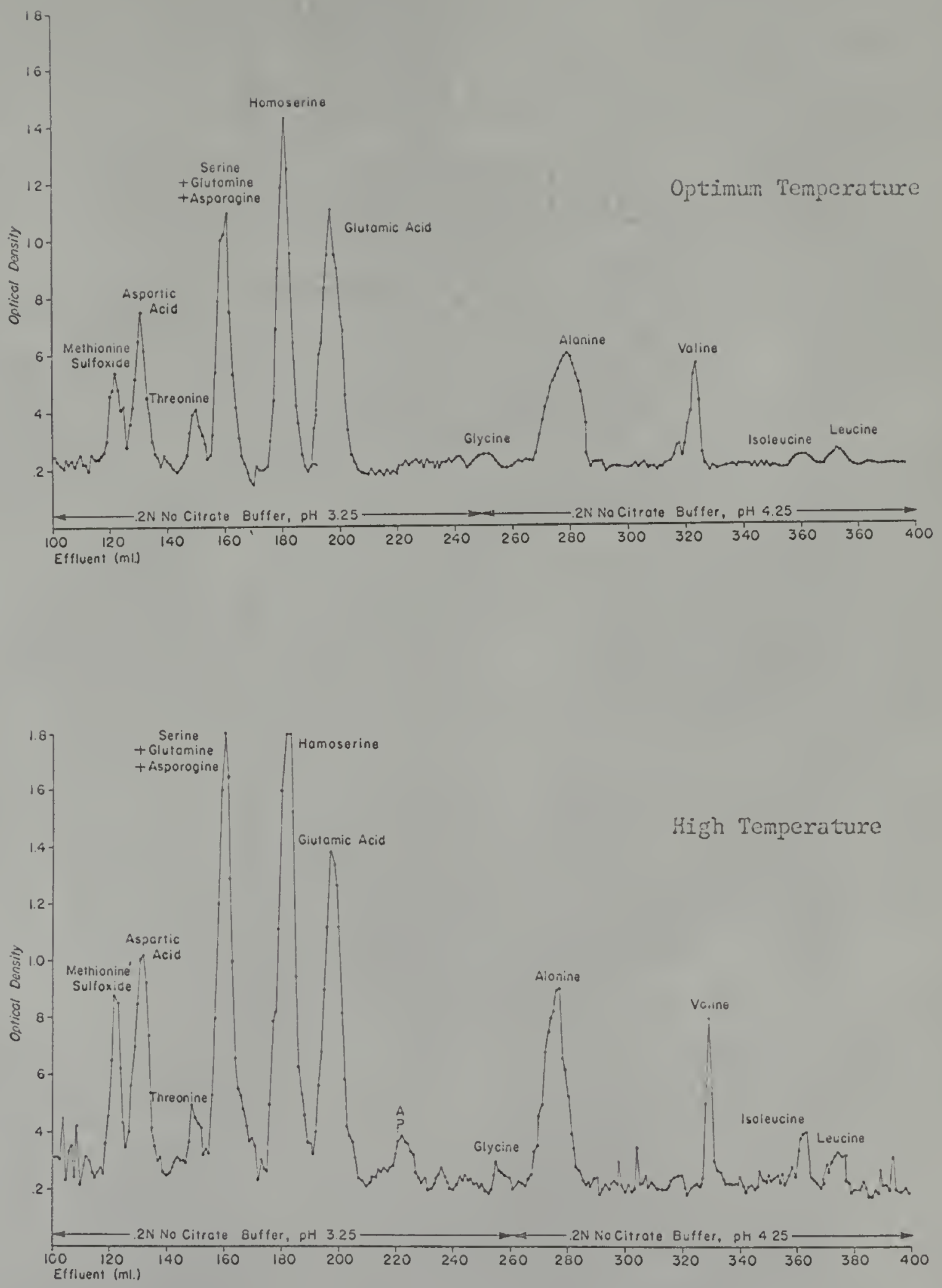

PIG. II 
while under the high temperature condition there was a large amount of amide. Methionine sulfoxide was also decreased in the optimum condition, while it was still high at high temperature conditions (Table 10 and Figure 12). The only amino acid which was increased at both temperatures was homoserine. At the optimum temperature condition, the amount of aspartic acid was very low while glutamic acid and alanine were not decreased. At the high temperature there was only a Iittle decrease in aspartic acia. The unknown A was very high at the high temperature (higher than in any other sampling period), while at the optimum temperature it was absent the same as in the previous sample. At high temperature, lysine, which was absent in the previous sample, was again present while histidine became very low at both temperature conditions.

\section{Protein Estimation}

The results of protein measurements in leaves of the plants under high and optimus temperature conditions, for five different perioàs of saming, are given in Table 11 and in Figure 17.

The results are presented in terms of mg equivalent of bovine serum albumin per gm of fresh weight. Protein determinations were not from the same plant materials that were used for amino acia studies but rather from the same 


\section{TABE 10}

Amino Acid Content of Leaves - Fifth Period of Sampling

\begin{tabular}{|c|c|c|c|}
\hline \multirow{2}{*}{ Amino acie } & \multicolumn{2}{|c|}{$\begin{array}{l}\text { jin per gram fresh weight } \\
\text { cemperature }\end{array}$} & \multirow[b]{2}{*}{ Ratio } \\
\hline & Cotimum & High & \\
\hline Methionine suifoxide & 0.16 & 0.60 & 3.75 \\
\hline Aspartic acid & 0.34 & 1.30 & 3.82 \\
\hline Threonine & 0.36 & 0.58 & 1.61 \\
\hline Serine & 0.92 & 1.80 & 1.95 \\
\hline Asparagine & 0.14 & 1.14 & 8.14 \\
\hline Glutamine & Irace & 0.34 & -- \\
\hline Homoserine & 3.45 & 2.97 & 8.60 \\
\hline Glutamic acid & 1.63 & 2.73 & 1.67 \\
\hline Proline & Trace & Present & -- \\
\hline Unknown A & -- & 0.65 & -- \\
\hline Glycine & 0.43 & 0.24 & 0.55 \\
\hline Alanine & 1.55 & 2.92 & 1.88 \\
\hline Valine & 0.23 & 0.52 & 2.26 \\
\hline Isoleucine & 0.12 & 0.23 & 1.91 \\
\hline Leucine & 0.06 & 0.07 & 1.16 \\
\hline $\begin{array}{l}\text { Tyrosine plus } \\
\text { phenylalanine }\end{array}$ & 0.29 & 0.81 & 4.20 \\
\hline$\gamma$-aminobutyric acid & 0.72 & 1.20 & 1.56 \\
\hline Lysine & 0.24 & 0.14 & 0.58 \\
\hline Histidine & Trace & Trace & -- \\
\hline Arginine & 0.12 & Trace & -- \\
\hline
\end{tabular}


Fig. 12. Chromatograms of amino acid constituents of leaves at optimum and high temperature. (Fifth period of sampling.) 

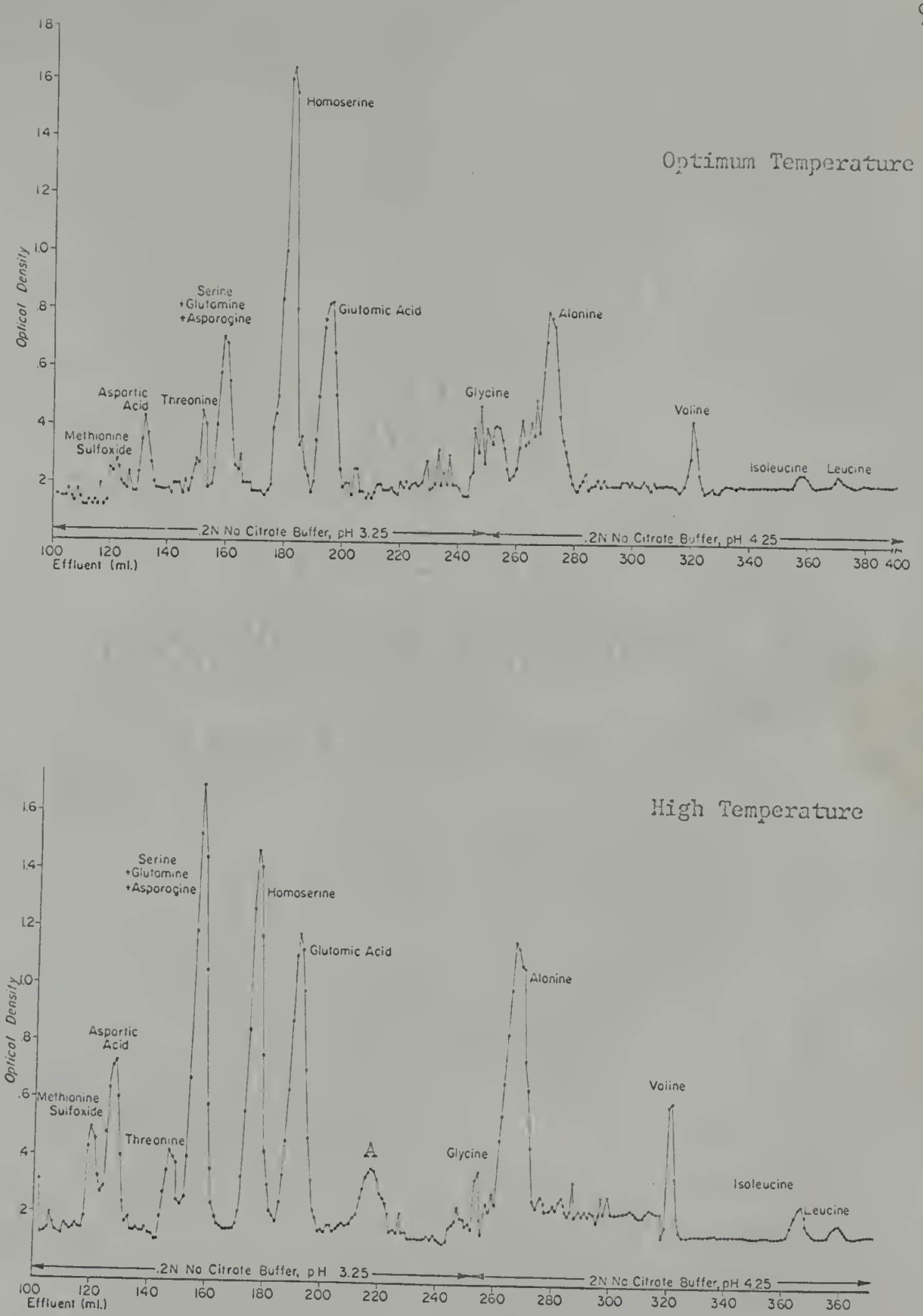

FIG. 22 
variety of plants which were grom later under (as nearly as possible) the same conditions. In the first sample, which was taken seven aays aften the seeds were planted, protein content was high in plants under both temperature regimes but it was a bit higher in the optimum temperature. High protein content at this sample period could result from solublization and translocation of proteins from the cotyledons to the youns, yet not completely expanded leaves. At the second sample which was taken two weeks after planting, there was a sharp decrease in protein concentration of plants grown at the two temperature conditions, when compared with the first sample. Again, the protein concentration was higher under the optimum than at the high temperature condition.

The third sampling was made 21 days after planting at high temperature and 23 days arter planting at optimum conditions in order to sample at the same plastochron index (P.I.). At this sampling period there was a sharp increase in protein content of the plants at the two conditions. Once again the total protein of the plants at the optimum temperature condition was higher than that of the plants at the high temperature regime. The great increase in protein content over the previous sampling may have resulted from: increased photosynthetic activity; a decrease in the rate of growth (unäer both temperature conditions); and finally, 


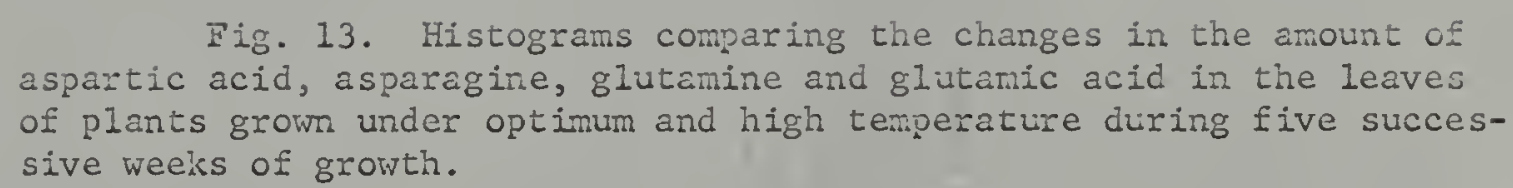




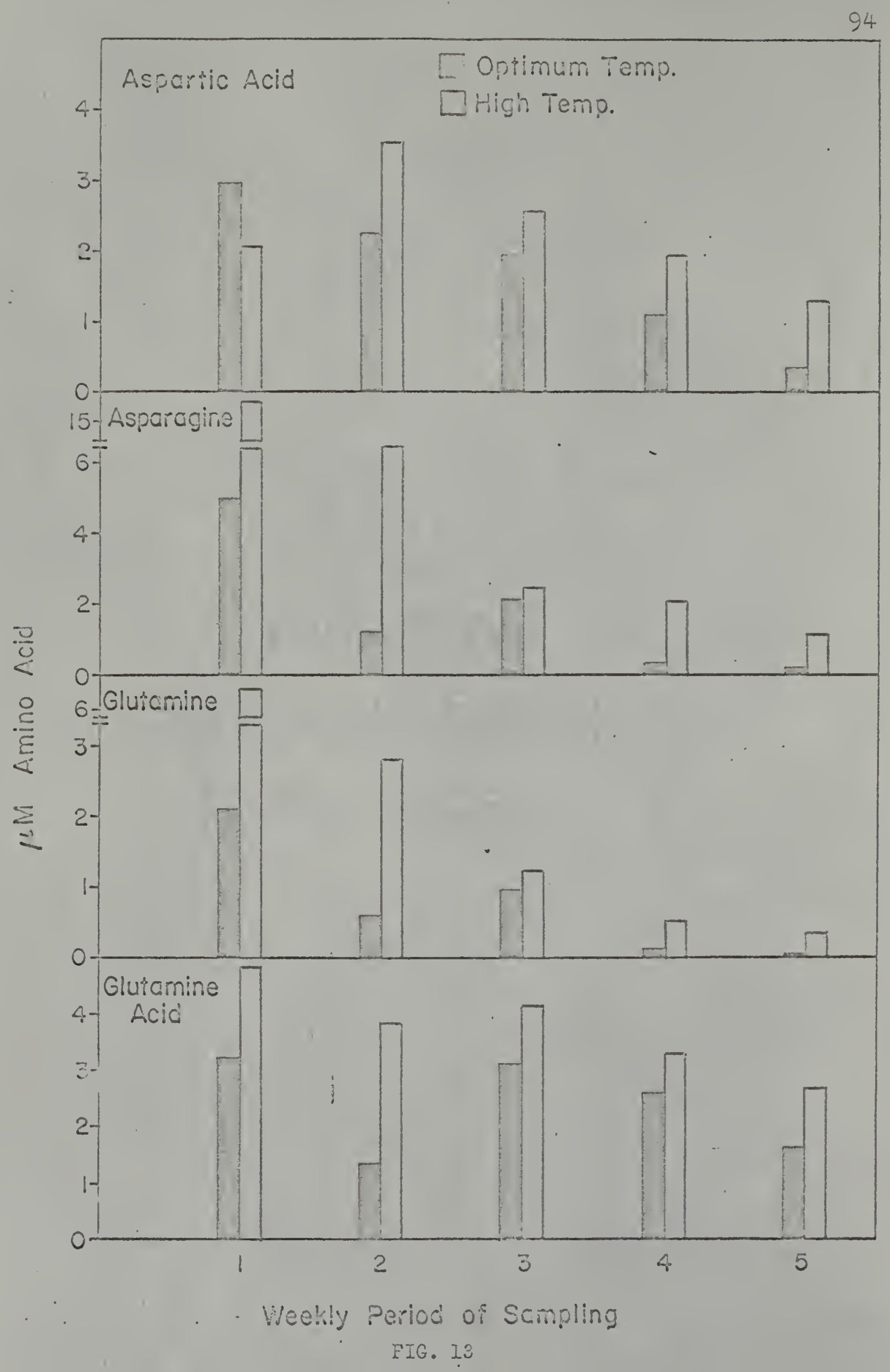


Eig. 14. Histograms comparing the changes in the amount of alanine, serine, glycine and threonine in the leaves of plants grown under optimum and high temperature during five successive weeks of growth. 
Alanine

E Optimum Tanp.

$\square$ High Tem?.

$-$

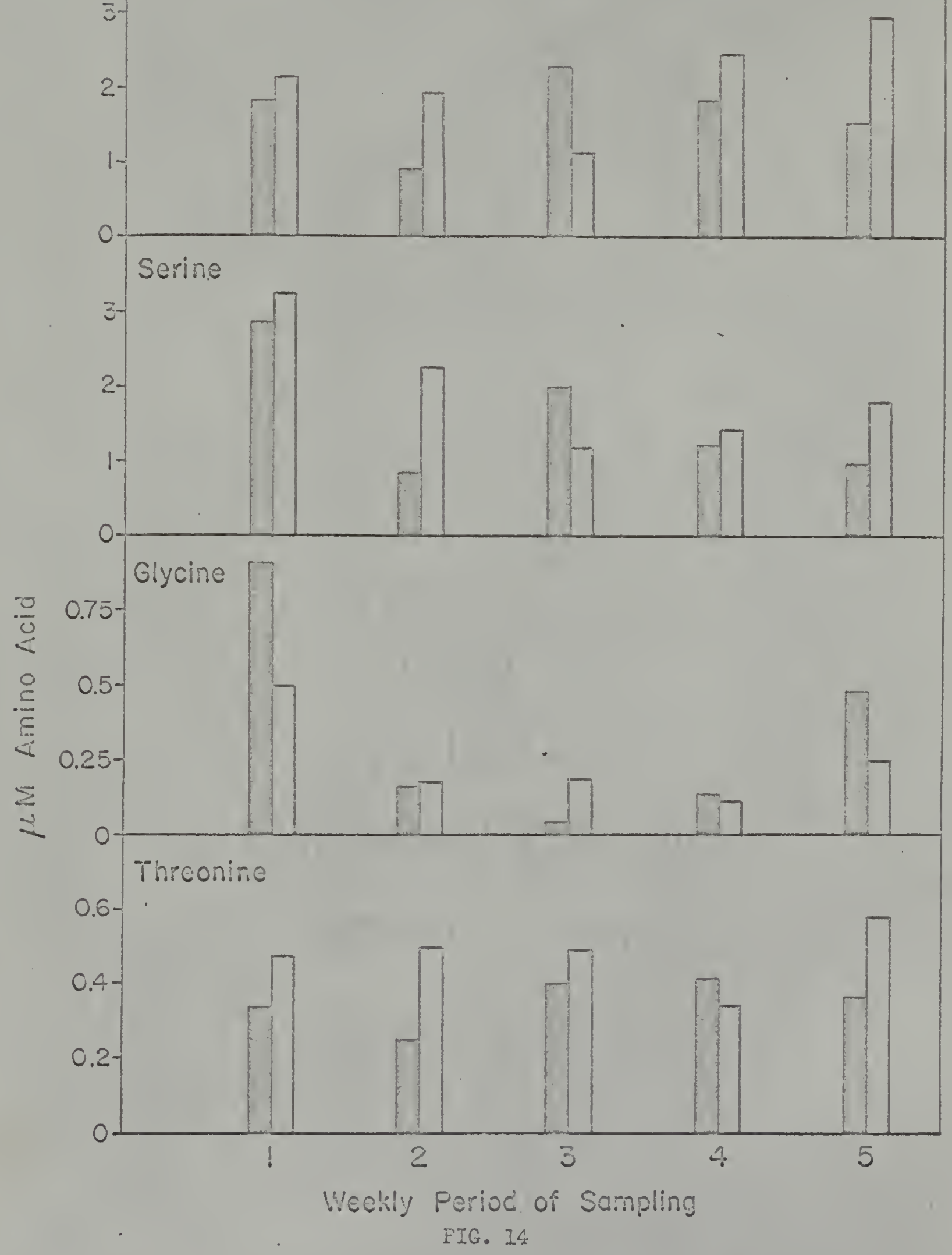


Fig. 15. Histograms comparing the changes in the amount of homoserine, valine, leucine and isoleucine in the leaves of plants grown under optimum and high temperature during five successive weeks of growth. 


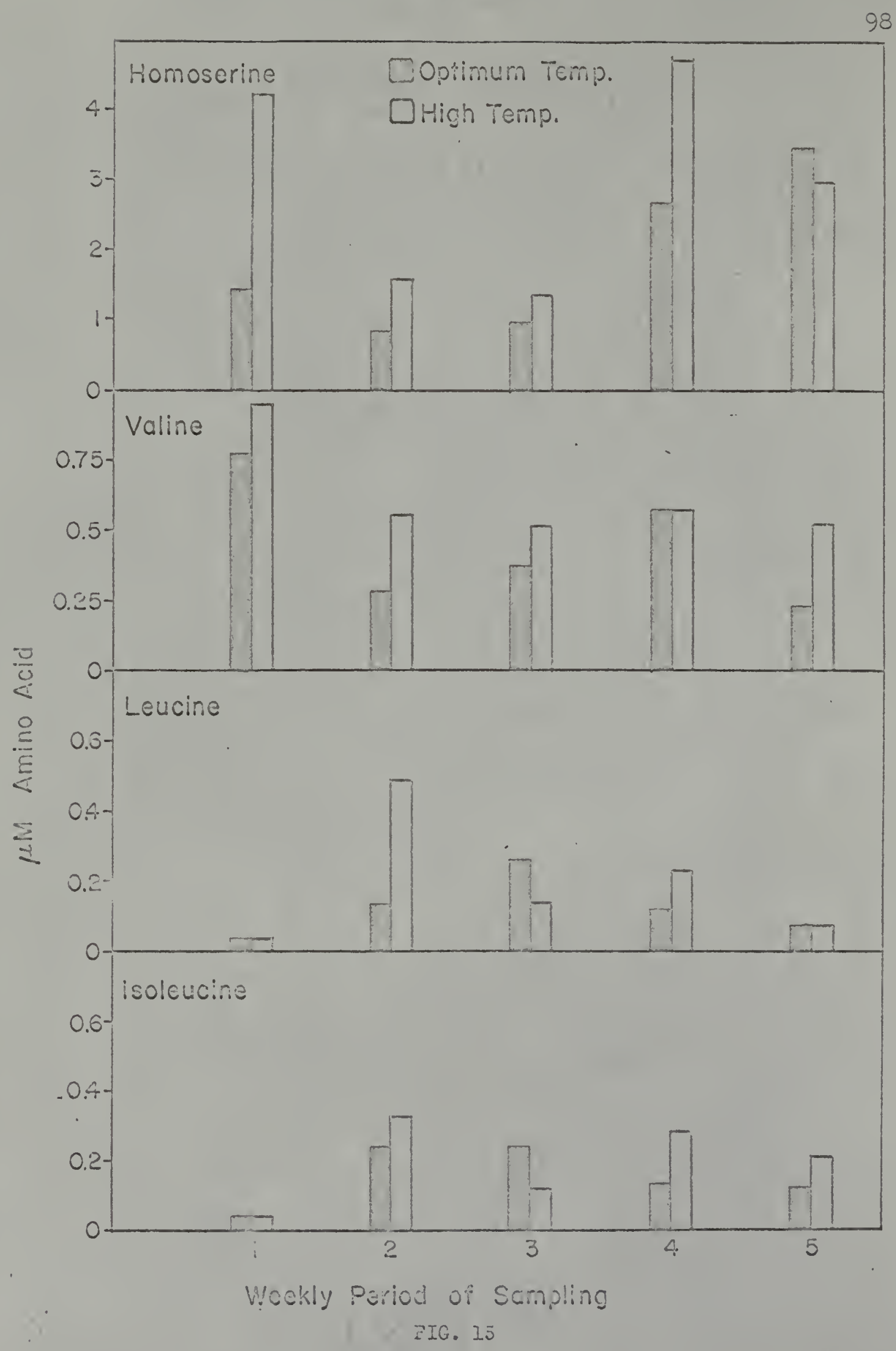





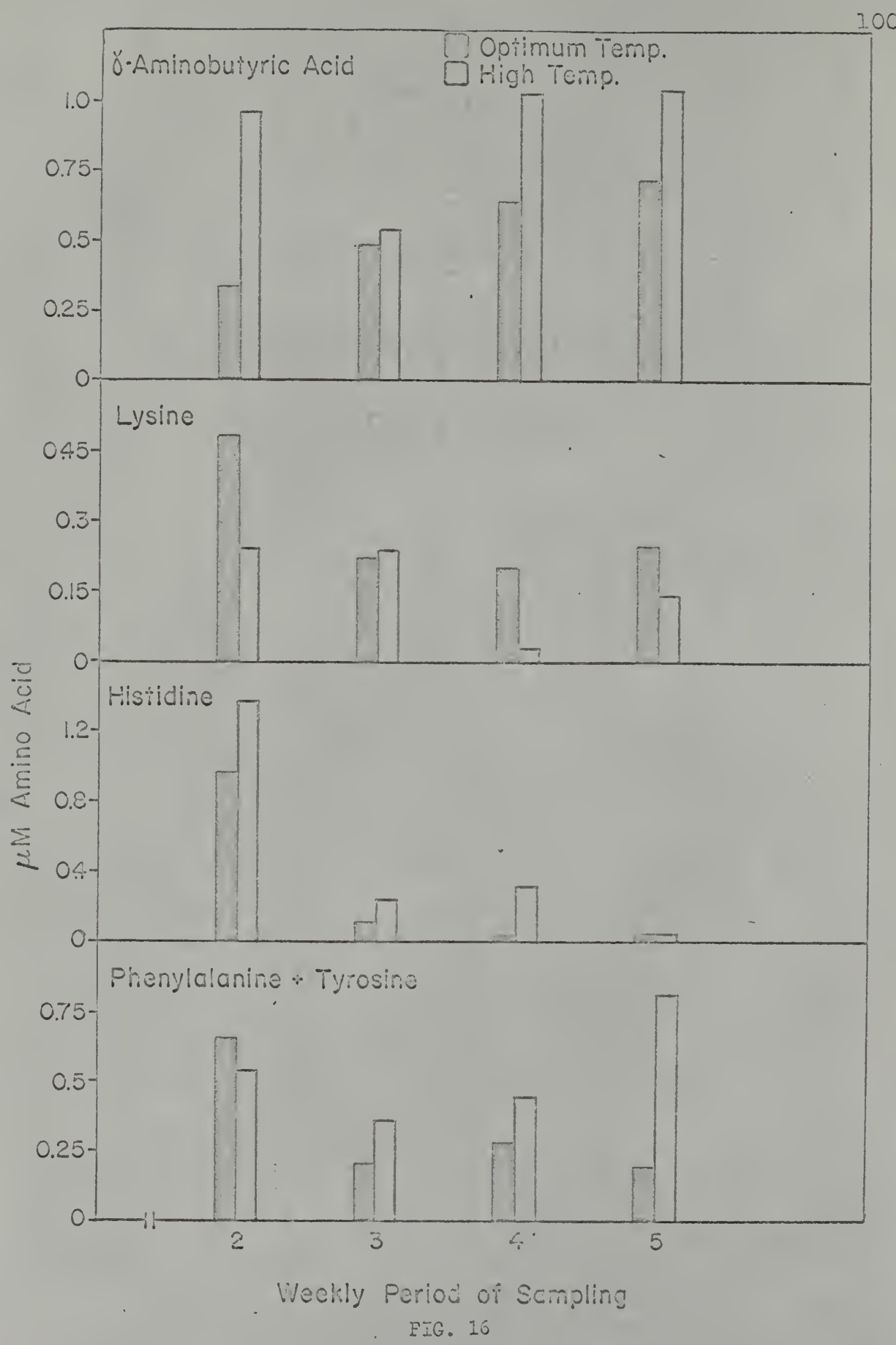


an increase in percent any weight of leaves. The data on protein concentration and the amino acid content at this same stage indicated that zeaves of this age not only have a high capacity for productng or storing amino acids but also a high capacity for incorporating the amino acias into proteins.

The fourth sampling was made during flowering and approximately four days after the first flower bud formation (28 àys and 30 days from planting at high and optimum temperature, respectively). With the fourth sampling there was a sharp decrease over the previous sampling period in protein content of plants at the optimum temperature condition while the protein content of plants at high temperature was not changed since the previous sampling. Probably the greater reproductive activity of the plants at the optimum temperature resulted in a mobilization of protein to the reproductive tissue and away from the leaves.

The last sampling was race a week arter the fourth sampling period; plants under the optirnm temperature condition had small fruits by this time. However, there was only a small decrease of protein content of plants growing under both temperature regimes. Fesults are shown in Figure 17 and Table 11. 
TABLE 11

Protein Content of Leaves*

\begin{tabular}{|c|c|c|}
\hline $\begin{array}{c}\text { Sample age } \\
\text { (weeks after } \\
\text { planting) } \\
\end{array}$ & $\begin{array}{c}\text { Protein content } \\
\mathrm{mg} / \mathrm{gm} \\
\text { optimum temperature }\end{array}$ & $\begin{array}{c}\text { Protein content } \\
\text { mg/gm } \\
\text { high temperature }\end{array}$ \\
\hline 1 & 50.4 & 42.1 \\
\hline 2 & 26.5 & 18.0 \\
\hline 3 & 40.5 & 28.4 \\
\hline 4 & 25.8 & 30.1 \\
\hline 5 & 24.8 & 26.4 \\
\hline
\end{tabular}

*Values are given in terms of mg equivalent of bovine serum albumin. 
Eig. 17. Total soluble protein content of leaves of the plants grown under optimum and high temperature durirg five successive weeks of growth. Amount of protein is given in tems of $\mathrm{mg}$ equivaient of bovine serum albumin.

Fig. 18. Total amino acid content of leaves of plants grown under optimum and high temperature conditions curing five successive weeks of growth. Amount of amino acid is given in terms of pnole per gn fresh weight of leaves. 


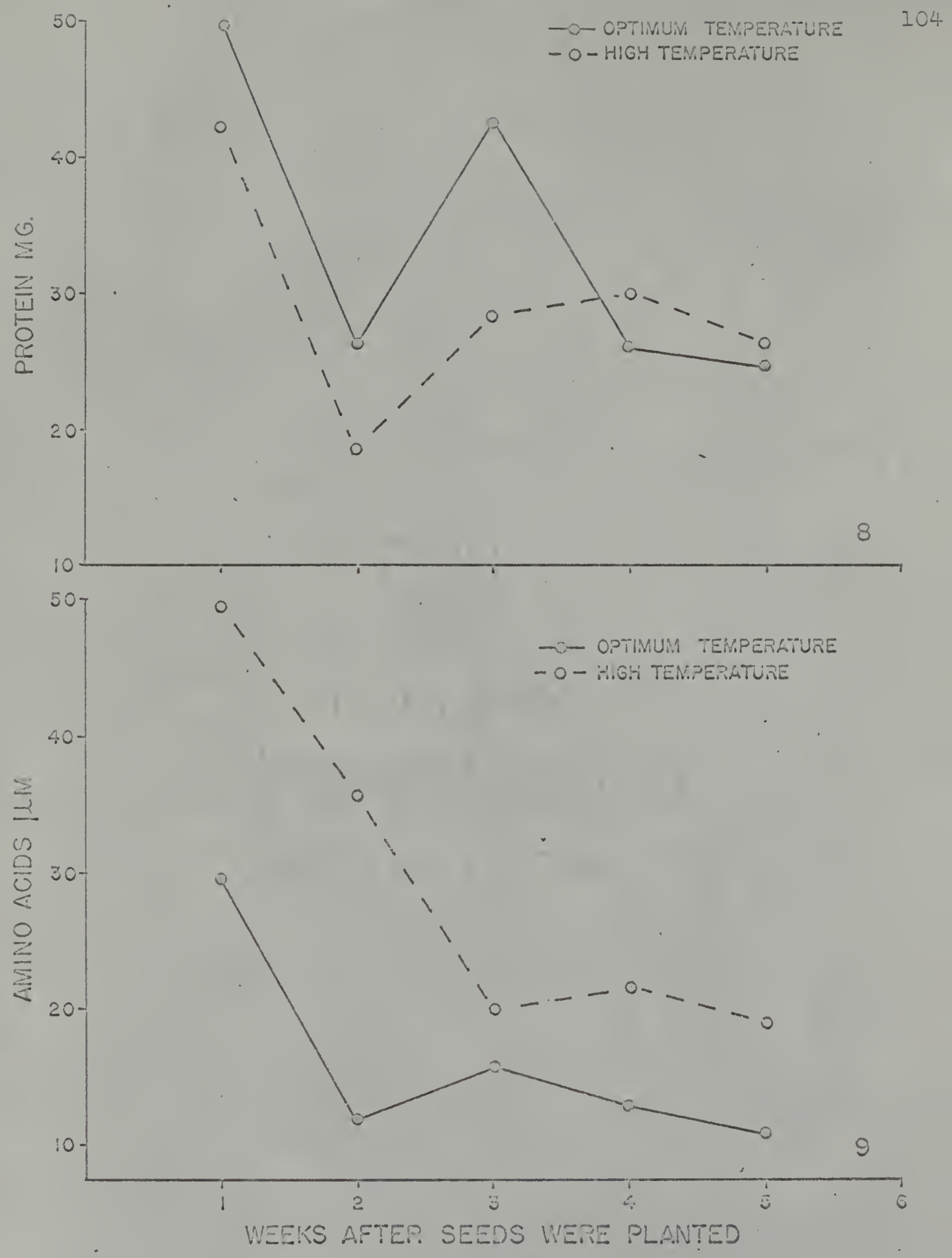

FIGS. 17 and 18 


\section{The Effects of Added Metabolites at High Temperature}

Tihe purpose of experixcrtation in this arca ras to examine the effects of varicus chenicals (metabolites) which have been used jy others $(31,32)$ to inhibit or decrease the injuries in plants caused by high temperatures. Identical conditions were used for these tests as had been used in the previous amino acia studies. 111 experiments with added metabolites were done in duplicate with 40 to 60 piants in each test.

\section{A. Eucrose effect}

Treatment of the plants with sucrose did not prevent the higin temperature injuries according to the data ojtained. Addition of sucrose for three weeks to pea plants under high temperature conditions did not increase the height of plant, iresh weight, dry weight, flowering on fruit fomation. In fact, the 10 per cent concentration of sucrose used as a spray (a concentration used by others) (32), was observed to be quite an inhibitor of growth. After a short time of treatment with that concentration, the entire group of test plants dried up. Later a dilute ( $I$ per cent) solution of sucrose was tried on the plants for several weaks under high and optimum temperature conditions, the plants remained healting but the results obtained were never clearcut. The observations were consistent with earlier work in this field 
With other varieties of peas which showed that the beneficial effect of sucrose was limited to the condition where the high temperature was only a few degees more than optimum (32) while in this experiment the temperature was ajout $8^{\circ} \mathrm{C}$. higher than the optimum. Possibly in these experiments, the detrimental effects of high temperature was not simply a aecrease of carbohydrates.

\section{Effects of vitamin 3 complex}

Four weeks of treatments with vitamin $B$ complex as a spray on plants under high temperature conditions caused an increase over the control plants of approximately 12 per cent in height and 11 per cent in fresh weight. No marked effects on dry weight and fruit formation were observed, although the number of flowers was somewhat greater on the treated than on the untreated plants. These results did not show as great an efiect of vitamin $B$ as those obtained by other workers with a äfferent variety of peas (32) or witi other plants at stib-optimal temperatures (40).

C. Effects of other treatrents

No beneficial effects were obtained by treatment of plants with a solution of nucleosides or with vitamin $C$ as a leaf spray. 


\section{General comments on metabolite treatments}

The failure of severai motabolites to reduce on prevent lesions in one variety oz pea piant grown under high temperature conditions seems to inäicate that there maj not be a single lesion due to high temperature that is universal among different varieties of a species of plant. Fowever, complications exist which attach reservations to this statement. It is possible that one reason for the insignificant result in our experiments and the inconsistencies in results of others $(32,40,42)$ could be the inaccessibility of the metabolites to the point of need because of low rate of absorption through the epidermal tissue of leaves, of destruction of the metabolite on or in the plant, or of failure of adequate translocation within the tissues. Another problem in interpretation of experiments of this type can be the variation of effect wh thanying degree of high temperature stiress. As the temperature increases, the number of critical reactions damaged by high temperature may increase, and so the netabolites needed to be supplemented. under different temperature conditions may not always be the sare. Such qualifying observations were also stated in the case of research on different strains of Arabidopsis by Langridge (40) where difrerent metabolites (biotin or nucleotides) were needed for different strains of srabidopsis. Combinations of scveral difzerent metabolites at different 
temperature regimes may be neeced to stop or reduce the injuries causec by supra-optimal tomperature, and this has been sionn to be true in the case of many microorgarisms $(42)$. 


\section{SUTHEY LIN OOHOUSIOAS}

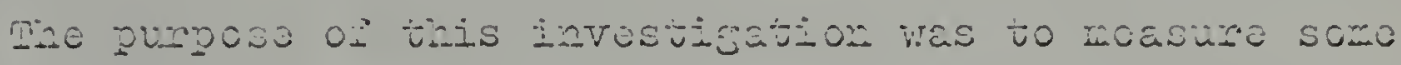

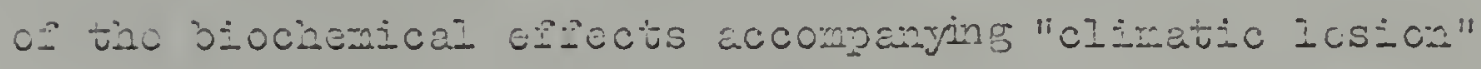
(7), specificaliy, the bicchomicul elects of supan-optimal temperatures. The plant naterial chosen was the pea (pisum setivin I. Var. Greater Progress). Data rere cbtained which showe thet the tomperaturo chosen for high on supracutinal ( $23^{\circ} \mathrm{C}$. night anc $30^{\circ} \mathrm{C}$. day) àda prociuce sore citratic lesicne without kilitho the piant. Growth, as Loasurec by increase in height and by tncrease in wet anch äny veight, was less (aften tro vecks) in tise plants grom at high temperatire than in those grova at the optimun. CAnorophyil contert was less at high tompurature, ana fruit

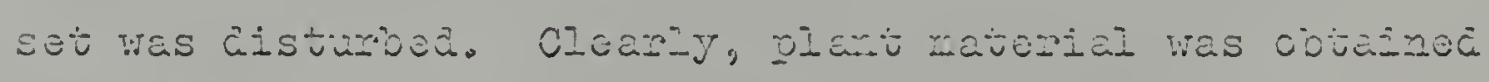
Which was suitabio for the assescaent of the biochemical

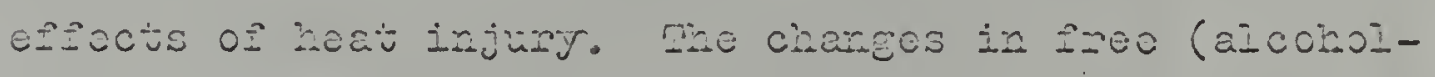
scluble) amino actis and total sclülo provetn were selectod For investigation. Data are presonted to show the reelit chenges in the concentration of each of 13 incisvidual amixo actas th extracts of leavos throundicht the vegetavive stage of the pea plant and into the reproductive stage for plants grown at high and at optinum tezponature (170 C. nisht ana $23^{\circ}$ C. बंä). 
A great deal of caution was exercised to obtain extracts from the tro groups 0 plants at the same physiological stage in order to be able to study the effects of high temperature per se rather than a secondary effect. This precaution was achieved by sampling from (at optimum and hiof temperature) plants with very similar plastochron incices at any sampling perioc. That is, physiological aoe, rather than chronological age, was the criterion for sampling time.

Amino acids were found to be resporsivo both quantitatively and qualitatively to the temperatures at which the piants were grown.

At all stages of growth, the total free amino acid content of leaves of pea plants grown at hion temperature was hicher than that of pianti grom ai optimum temperature. Mhere were, however, changes in concentratiol a'v various stages of growth in both the nigh temperature and optimum temperature plant material. Tise total amino acid in leaves aropped after two weeks of growth undor both tomperature conditions; however, the drop in the plants grown at optimum temperature was greater than in the plants grow at high temperature. At later times, the free amino acid content of leaves of plants grown at high temperature remained almost constant while continuing to decrease in the plants Erow uncer optimum temperature conditions. Since fruit set 
was observed under optimum conditions by about the fifith weels of growth but never at high temperature, it was considered that at least part of the aifference in amino acid content in the last samplings might have been due to changes in metabolism in passing from a vegetative to a reproductive stage in the plants grown at optimum temperature.

$$
\text { Although most incividual amino acids wich were }
$$

quantitatively measured were ai least somerhat higher in the plants grown at high temperature, some were more mankediy increased than others. Glutamic and aspartic acicis and, to a greater extent, their amides, glutamine and asparagine, were at a very much higher concentration at the kigh temperature regime, especially during the first week or two oI the life of the plants. Alcohol-soluble nitrogenous constituents which appear to bo small peptiōes, and also an amino acid tentatively identified as methionine sulfoxide, were greatly elevated in the plants growing under the high terperature regime. An amino acid provisionally identified as $\alpha$-amino adipic acid appeared in extracts of leaves of young plants grown at high temoerature and increased with increasing age of the plants until it became one of the major components of the Iree amino acias of older piants. On the other hand, the amount of this amino acid in leaf extracts of plants grow at optimum temperature was very Iow after a week of growth, and after two weels it disappeared completely. 
Less extensive analyses of roots (exarinea only at two weeks after planting) also inäicated similar epfects of high temperature on the free amino acid contert of roots. That is, the amino acid content was higher in roots of plants grown at high temperature than in roots of plants of the same plastochron incex grown at optimum temperatures. Fovever, with respect to certain inaividual amino acids there vere some quantitative aifferences from the effects observed in leaves.

Motal protein content of leaves also was determineà at weekly intervals throughout the vegetative stage and into the reproductive stage in two groups of plants grown at two temperature regimes. As in the case of amino acids, there were marked differences between the two groups. However, in contrast to the results on free amino acids, there was less protein in the leaves of the high temperature plants throughout the vegetative stages. Then fruit set occurrea in the optimum tomperature senios, the protein content aropped until it was equal to that of the high temperature plants (the latter did not set complete fruit).

The increase of free amino acids and decrease in protein content observed at high temperature suggests that the free amino acids were produced at the expense of the protein, that is, by increased protein degradation. This would be in agrecment with the hypothesis of Petinov (60). 
Potinor showed, in limitea semi-quantitative studies, that amino acids romained at higher concentration in exciseá Eeaves he?d at high temperatume even when inhioitors oi the Krebs cycle were applied to the tissues; that is, when amino acia synthesis from carbohydrate was supposedly blocked by the inhibitors.

Certain Peatures of these data do not support the protein degradation hypothesis as the only reason for amino acid increase at high temperature, but rather, tend to support the notion that the increase in free amino acias resulting unaer the stress of high temperature was the reslit of increased synthesis as suggested by stewara (70). The work of steward also involved environmental stress (in the mint plant, Mentha piperita) other than temperature, such as photoperiod and nutritional variables. It was shown that there was an increase in Krebs cjcle acids and a-keto acias at the same time that an increase in amino acids occurred. While no data were obtained on the Knebs cycle aciōs and/or $\alpha$-keto acids in this present stuaj, an elevation of non-protein amino acids at high temperature was observed. In fact, this increase even in some cases exceeded the increase in protein amino acias. Further, the changes in amino acid content with stage of maturity were not reflected in inversely propontional changes in protein content. 
Attempts were made to prevent or cure by chemical means the "climatic lesions" incuced by high temperature. Ieaf sprays of various metabolites such as sucrose: a vitamin $B$ comolex mixture, vitamin $C$ and a mixture of nucleosides did not appreciably alter the effects of high temperature. 


\section{IITERATURE CITED}

1. Amoff, S. 1962. Dynamics of Amino Acids in Plants, in "Amino Acid Pools." Elsevier Publising Company, Amsterdam, New York.

2. Atwood, I. C. and F. Mukai. 1953. Indispensable gene function in Neurospora. Proc. Nat. Acad. Sci. Wasi. 39: 1027-35.

3. Barnett, H. I. and V. G. Iilly. 1948. The interrelated effects of vitamins, temperature, and pH upon vegetative growth of Sclerotinia camelliae. Am. J. Botany 35: 297-302.

4. Beinhart, G. 1962. Effect of temperature and light intensity on $\mathrm{CO}_{2}$ uptake, respiration anc growth of white clover. Plant Physiol. 37: 709-715.

5. Brownlow, W. J. and G. E. Wessman. 1960. Nutrition of Pasteurella pestis in chemically defined media at temperature $01^{\circ} 36^{\circ} \mathrm{C}$. to $38^{\circ} \mathrm{C}$. J. Bacteriol. $79: 299-304$.

6. Bonner, J. 1943. Effects of application of thiamin to cosmos. Botan. Gaz. 104: $475-479$.

7. 1957. The chemical cure of climatic lesions. Iing, and Sci. 20:28-30.

8. … 1960. The biology of plant growth. In: Growth In Iiving System. M. X. Zarrow, ed. pp. 439-452. (Basic Books Inc., Pubiisher. N. Y.).

9. CampbelI, I. I. and 0. B. Williams. 1953. The effects of temperature on the nutritional requirements of facultative and obligate thermophilic bacteria. J. Bacteriol. 65: 141-145.

10. Copeland, J. J. 1936. Blue green algae (Thermophilic blue green algae, yellow-stone annual.) Annal ôे New York Academy of Science 36: 1-239.

11. Davern, C.I. 1959. Ph.D. Dissertation, Chemotherapy of high temperature inhibition of plant growtin. Cal. Inst. of Tech. Pasadena, California. 
12. Erickson, R. O. and M. Michelini. 195?. The plastochron index. Am. J. Botany 44: 297-305.

13. Exickson, R. O. 1960. Nomogram for the pastochron index. Am. J. Botany 47: 350-351.

14. Fries, I. 1953. Factors promoting growth of coorinus fimetarius ( $I_{.}$) under high temperature conditions. Physiol. plantarium 6: 55I-563.

15. Galston, A. W. and M. I. Hand. 1949. Adenine as a growth factor for etiolated peas and its relation to the thermal inactivation of growth. Arch. Biochem. 22: $434-443$.

16. Galston, A. W. 1957. In: The Ixperimental Control of Plant Growth. F. W. Went, ed. Chronica Botanica Co., Waltham, Nass. Po. 313-317.

17. 1959. Adenine and plant grouth. Science $12 \dot{9}: 357$.

18. Greer, S. and S. Zamenhof. 1962. Studies on depurination of DNA by heat. M. Molec. Biol. 4: $123-141$.

19. Hertman, I. and R. J. Ben-Gurion. 1959. High temperature effects on microorganism. Gen. Microbio. 21: 135-14j.

20. Hewitt, S. P. and O. F. Curtis. 1948. Effect of temperature on loss of dry matter and carbohyärates from leaves by respiration and translocation. Am. J. Botany 35: 746-755.

21. Highkin, H. R. 1956. Biology. Cal. Inst. rech. 79. (Reference obtained from Davern th.)

22. 1958. Temperature-incuced variability in peas. Am. J. Botany 45: 626-631.

23. 1958. Temperature-induced variation in peas. Am. J. Botany 45: 631-632.

24. Horowitz, F. F. and M. Fing. 1953. Genetic determination of tyrosinase thermostability in Neurospora. Genetics 38: 360-374.

25. Houlahan, M. B. and H. I. Mitchell. 1947. A suppressor in Neurospora and its use as evidence for allelism. Proc. Nat. Acad. Science 33: 223-228. 
26. Howell, Robert $U$. and I. Jackson. 1958. Physiolorical factors affecting composition of soybecns. II. Response of oil and other constituents of soybeans to temperature uncion controlled conditions. Agron. Jour. 50: 664-667.

27. Funter, S. H., H. Baker, S. Aaronson, H. A. Nathan, I. Rodgiques, S. Lockvood, M. Sanders and R. A. Petersen. 1957. Growing Ochromonas malhamensis above $35^{\circ}$ C. J. Protozcol. 4:259-269.

28. Johnson, F. H., H. Eyring, and M. J. Polissar. 1954. The kinetic basis of moleculan biology. John Wiley and Sons, N. Y. Po. 187-214.

29. Johnson, Frank H. (Editor) 1957. Influence of temperature on biological systems. Amer. Physiol. Soc. Wash. D.C.

30. Kempner, E. S. 1963. Uoper temperature limit of life. Science 142: 1318-1319.

31. Ketellapper, I. J. and J. Bonner. 1961. The chemical basis of temperature responses in plarts. Plant Physiol. 36 suppl. XXI.

32. Ketellapoer, H. J. 1963. Temperature-induced chemical defects in higher plants. Plant Physiol. 38: 175179.

33. Koffler, H. 1957. Protoplasmic differences betreen mesophiles and thermophiles. Bacteriol. Rev. $21: 227-240$.

34. Iristoffersen, T. 1963. Interaction of photoperioa and temperature in growth and development of youns tomato plants (Iycopersicum esculentum, Mill.). Physiol. Plantarium Suppl. I

35. Kurtz, Edwin B., Jr. 2958. Chemical basis for adaptation in plants. Science 128: 115-118.

36. Laccard, J. 1961. Kinetics of high temperature effects on plants. Plant Physiol. 39: 220-225.

37. Lang, 4. 1956. Bolting and flowering in biennial Hyocyamus niger induced by gibberellin. Plant PAysiol. 31. SuppI. XXXV.

38. Iang, A. 1957. The effect of gibberellin upon flower formation. Proc. Nat. Acad. Sci. 45: 709-717. 
39. Langridge, J. 1958. A hypothesis of developmental selection exemplified by lethal and semi-lethal mutants of Arabicopsis. Aust. J. Biol. Sci. Il: 58-68.

40. Langridge, J. and B. Griffing. 1959. A study of high temperature lesions in Arabidonsis thaliana. Aust. J. Biol. Sci. 12: l17-135.

41. Iangridge, J. 1962. A genetic and molecular basis for heterosis in Arabidopsis and Drosophila. American Naturalist $96: 5-27$.

42. 1963. Biochemical aspects of temperature response. Annual Rev. of Plant Physiol. 14: $441-462$.

43. Lawrence, J. M. and D. R. Grant. 1963. Nitrogen mobilization in pea seedlings. II. Free Amino Acids. Plant Physiol. 38: 561-566.

44. Levitt, J. 1962. A Sulfhydryl-disulfide hypothesis of frost injury and resistance in plants. J. Theoret. Biol. 3: 355-391.

45. Ievitt, J., C. Y. Sullivan and N. O. Johnson. 1962. Sulfhydryl, a new factor in frost resistance. III. Relation of $\mathrm{S}$. $\mathrm{H}$. increase during hardening to protein, gluthatione and gluthalion oxidizing activity. P. Physiol. 37: 266-27I.

46. Locknart, J. A. 1958. The role of gibberellin in the control of pea growth by temperature. Planta, Bd. 52: $250-258$.

47. Iombert, R. G. and A. J. Iincle. 1958. Elfect of high temperature on yield of peas. P. Physiol. 33: $347-349$.

48. Iorenz, R. W. 1939. High temperature tolenance of Iorest trees. Minn. Agr. Expt. Sta. Tech. Bull. 141.

49. Lowry, C. H., N. J. Rosenorough, A. I. Farr and R. J. Randal1. 1951. Protein measurement with the Folin-phenol reagent. J. Biol. Chem. 193: 265-275.

50. Iowry, N. J. 1957. Nethod of protein determination. In: Method of Inzymology. III. Academic Press, New York. Pp. 448-449. 
51. Naas, W. K. 1950. A temperaure sensitive pantothenic less mutant of Escherichia coli. Bact. Proc. 128129.

52. Maas, W. K. and B. D. Davis. 1952. Production of an altered partathenate-syntiesizin; enzyme by a temperatur-sensitive mutant of ascherichia coli. Proc. Nat. 1cad. Sci. Wash. 38: $785-797$.

53. Maksymowych, R. and R. O. Erickson. 1960. Development of the lamina in xanthium italicum represented by the plastochron index. Am. J. Botany 47: 451-459.

54. McCune, D. 1956. Biology 1956. Cal. Inst. Tech. Reference obtained from Davern 什1.

55. McElroy, W. D. and H. K. Mitchell. 1946. Enzyme studies on a temperature-sensitive mutant of Neurospora. Federation Proc. 5: 376-379.

56. Michelini, Francis J. 1958. The plastochron index in developmental studies of xanthium italicum Naretti. Am. J. Botany 45: 525-533.

57. Mitchell, H. K. and M. B. Houlahan. 1945. Neurospora. IV. A temperature-sensitive riboflavinless mutant. Am. J. Botany 33: 31-35.

58. Moore, S., D. H. Spackman, and W. H. Stein. 1958. Chromato onaphy of Amino lcids on Sulforated polystyrene Resins. Anal. Chem. 30: 1185-1190.

59. Nightingale, G. T. 1935. Effects of temperature on growth, anatomy, and metabolism of apple and peach roots. Bot. Gaz. 96: 581-639.

60. Petinov, N. S. anci G. Mololatkovskii. 1960. The effect of respiratory inhibitors on heat resistance in plants. Mranslated from: Fiziologiya Rastenii, $7: 665-672$.

61. Pine, I. J. 1957. Studies on the Growth of Histoplasma capsulatum. III. Effects of thiamin and other vitamins on the growth of the yeast and mycelial phase of Histop? asma capsulatum.

62. Prosser, C. I. (Eaitor). 2958. Physiological Adaptation. American Physiol. Soc., Wash. D. C.

63. Rosen, F. 1956. A modified ninhydrin colorimetric analysis for amino acids. Arch. Biochem. and Biophys. 67: 10-15. 
64. Sasaoka, K. 1958. Studies on the formation of homoserine during the germination of the pea. Mem. Research Inst. Food Sci. Kyoto Univ. 14: $42-48$.

65. Sie, I. H. C., H. Sobotka and H. Baker. 1961. Factors converting mesophilic into thermophilic microorganisms. ivature 192: 86-87.

66. Sie, I. H. C. and H. Sobotka. 1961. Biochem. Biophys. Res. Commun., 6: 205-209.

67. Snedecor, G. W. 1956. Statistical methods applied to experiments in agriculture and biology. Iowa State College Press. Ames.

68. Spector, W. S. (Editor). 1956. Handbook of biological data (W. B. Saunders Co., Philadelphia.) 584 pp.

69. Stark, J. B. 1962. Use of ion-exchange resins to classify plant nitrogenous compounds in beet molasses. Anal. Biochem. 4: 103-109.

70. Steward, F. C., F. Crane, K. Miliar, R. M. Zacharius, R. Rabson and D. Margolis. 1959. Nutritional and envirommental effects on the nitrogen metabolism of plants. Symposia on the society for experimental biology. XIII. Utilization of nitrogen and its compounds by plants. Printed in Great Britain.

71. Steward, F. C. and J. F. Thompson. 1950. The nitrogenous constituents of plant with special reference to chromatographic method. Vol. I: 233-264. Ann. Rev. Plant Physiol.

72. Steward, F. C. and J. I. Pollard. 1962. The soluble nitrogenous constituents of plants, amino acid pools. Elsevier Publishing Company, Amsterảam, New York.

73. Thompson, J. F., R. M. Zacharius and F. C. Steward. 1951. Investigation on nitrogen compound and nitrogen metabolism in plants. (Reaction of nitrogen compounds with ninhydrin on paper-a quantitative procedure.) Plant physiol. 26: 375-347.

74. Thompson, J. F. et al. 1962. -Glutanyl peptides in plants. Amino acia pools. Elsevier Publishing Company, Amsterdam, NTew York. 
75. Thompson, J.F. and F. C. Steward. 1951. Variables in two-dimensional paper chromatography of nitrogen compounds, a quantitative procedure. Plant Physiol. 26: $421-440$.

76. Virtanen, A. I. and A. M. Berr. 1953. Formation of homoserine in geminating pea seeds. Acta Chem. Scand. 7: 1423-1424.

77. Went, F.W. and H. Hull. 1949. The effect of temperature upon translocation of carjohyarates in the tomato plant. Plant Physiol. 24: 505-526.

78. Went, F. W. 1957. The experimental control of plant growth. Chronica Botanica. Co., Waltham, Mass.

79. 1957. Some aspects of effects of temperature on plants. In: Influence of Temperature on Biological System. ed. Johnson. John Wiley and Sons Company, New York.

80. Yarwood, C. E. 1961. Acquired tolerance of leaves to heat. Science I34: 941-942.

81. Yarwood, C. I. 1961. Mranslocated heat injury. Plant Physiol. 36: 721-726. 


\section{BIOGRAPHICAI SKETCH}

The author, Esmail Hosseini Shokrail, was born in Tehran, Iran, May 1, 1935. He received his elementary education in Tehran and graduated from Alhorz High School, June, 1954.

He entered Tehran University, Tehran, Iran, in September, 1954, and received the degree of Licentiate of Biological Sciences in July, 1957. He was employed as Instructor of Plant Physiology at the Faculty of Science, Tehran University and at the same time continued graduate studies and received the degree of Post Iicentiate of Botany in June, 1960, and since then worked as assistant professor of plant physiology until July, 1962. In July, 1962, he received a Fulbright Travel Award, a Fellowship from the American Friends of the Middle East and a nonresident tuition scholarship from the University of Florida for graduate studies in the Botany Department of the University of Florida. He received a Research Assistantship from the Agricultural Experiment Station during the second and third years of graduate studies. He worked toward the degree of Doctor of Philosophy in Plant Physiology in the Botany Department which he received in April, 1965. He is a member of Alpha Zeta. 
This dissertation was prepared under the direction of the chairman of the candidate's supervisory committee and has been approved by all members of that committee. It has been submitted to the Dean of the College of Agriculture and to the Graduate Council, and was approved as partial fulfillment of the requirements for the degree of Doctor of Philosophy.

April 24, 1965

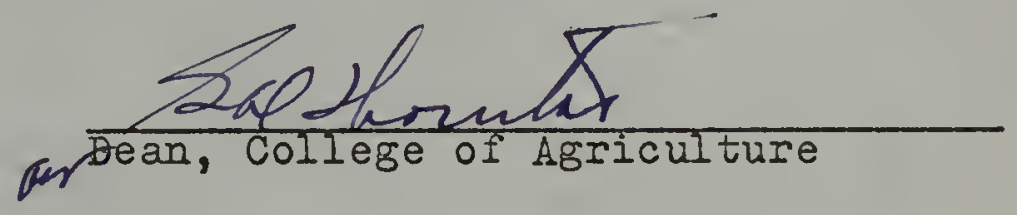

Dean, Graduate School

SUPERVISORY COMIITIEE:

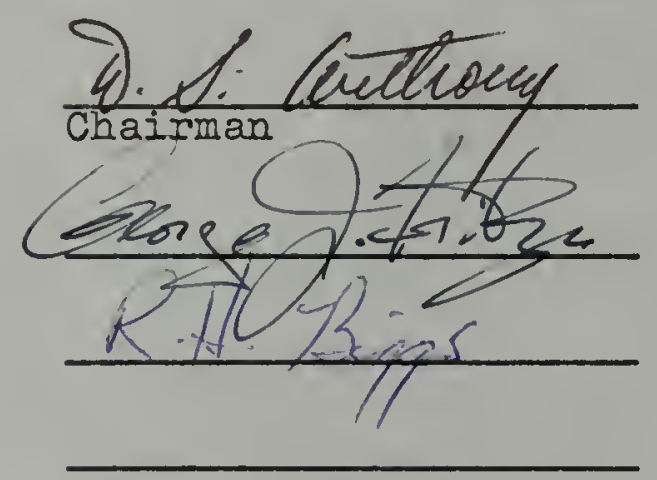




$$
\begin{gathered}
9 \\
2004: \ldots 1,5
\end{gathered}
$$

